\title{
The Influence of Fire-Induced Surface Changes on the Diurnal Temperature Changes over the Hayman Fire Scar ${ }^{\mathscr{O}}$
}

\author{
MARgARET A. LEMONE \\ National Center for Atmospheric Research, ${ }^{\mathrm{a}}$ Boulder, Colorado \\ BINGCHENG WAN \\ Institute for Atmospheric Physics, Chinese Academy of Sciences, Beijing, China \\ Michael Barlage AND Fei CHEN \\ National Center for Atmospheric Research, Boulder, Colorado
}

(Manuscript received 29 March 2016, in final form 20 September 2016)

\begin{abstract}
During the 2010 Bio-Hydro-Atmosphere Interactions of Energy, Aerosols, Carbon, $\mathrm{H}_{2} \mathrm{O}$, and Nitrogen (BEACHON) experiment in Colorado, nighttime temperatures over a site within the 2002 "Hayman" fire scar were considerably warmer than over the "Manitou" site that was located outside the fire scar. Temperature differences reached up to $7 \mathrm{~K}$ at the surface and extended to an average of $500 \mathrm{~m}$ AGL. Afternoon temperatures through the planetary boundary layer (PBL) were similar at the two locations. PBL growth during the day was more rapid at Manitou until 1300 local time, after which the two daytime PBLs had similar temperatures and depths. Observations were taken in fair weather, with weak winds. Runs of the Advanced Research version of the Weather Research and Forecasting model (ARW-WRF) coupled to the Noah-MP land surface model suggest that the fire-induced loss of surface and soil organic matter accounted for the 3-4-K warming at Hayman relative to its prefire state, more than compensating for the cooling due to the fire-induced change in vegetation from forest to grassland. Modeled surface fluxes and soil temperature and moisture changes were consistent with observational studies comparing several-year-old fire scars with adjacent unaffected forests. The remaining difference between the two sites is likely from cold-air pooling at Manitou. It was necessary to increase vertical resolution and replace terrain-following diffusion with horizontal diffusion in ARW-WRF to better capture nighttime near-surface temperature and winds. Daytime PBL growth and afternoon temperature profiles were reasonably reproduced by the basic run with postfire conditions. Winds above the surface were only fairly represented, and refinements made to capture cold pooling degraded daytime temperature profiles slightly.
\end{abstract}

\section{Introduction}

In June of 2002, over $550 \mathrm{~km}^{2}$ of evergreen (ponderosa pine and Douglas fir) forest west of Colorado Springs, Colorado, was devastated by the "Hayman" fire (Fig. 1). In August of 2010 as part of the Bio-Hydro-Atmosphere

Supplemental information related to this paper is available at the Journals Online website: http://dx.doi.org/10.1175/ JAMC-D-16-0132.s1.

${ }^{a}$ The National Center for Atmospheric Research is sponsored by the National Science Foundation.

Corresponding author e-mail: Margaret A. LeMone, lemone@ ucar.edu
Interactions of Energy, Aerosols, Carbon, $\mathrm{H}_{2} \mathrm{O}$, and Nitrogen (BEACHON) project, the impacts of the vegetation and soil changes in the fire scar were assessed by comparing fair-weather meteorological observations at two sites that are $15 \mathrm{~km}$ apart: one within the fire scar and one outside it. The fire-impacted site (hereinafter Hayman) had a ground cover of sparse grass with charred tree stumps, and the unaffected site (hereinafter Manitou) was surrounded by ponderosa pine on the order of $10 \mathrm{~m}$ high. The weather was mostly fair with weak winds during the period of observations.

The drastic change in vegetation and likely reduction of surface and soil organic matter at Hayman can potentially have a large impact on postfire atmospheresurface interaction. The high-severity-fire designation in 


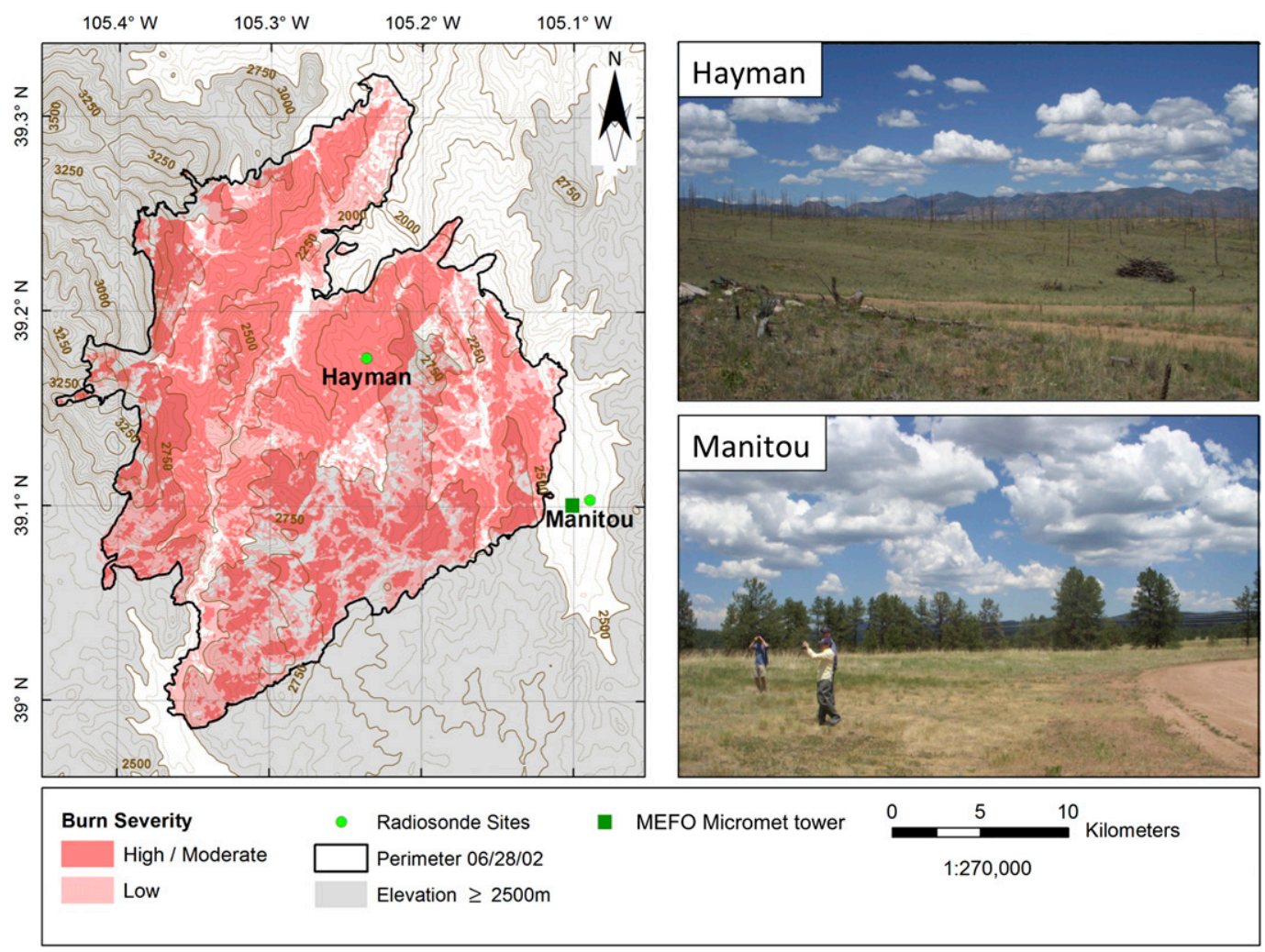

FIG. 1. Fire scar and contours with Hayman and Manitou land cover. (left) Terrain with contours at 50-m intervals and thick contours at 250-m intervals. Fire extent, burn severity, and observation sites are included. Terrain above $2500 \mathrm{~m}$ is gray shaded. The burn-severity data are from the U.S. Geological Survey (http://burnseverity.cr.usgs.gov/ show_fire.php?intID=55). (right) Photographs of the (top) Hayman and (bottom) Manitou sites. The fact that all that remains of the trees at Hayman is charred stumps is consistent with a severe burn.

Fig. 1 is consistent with near-complete to complete loss of surface leaf litter and organic matter in the upper soil layer (definitions are in Table 2 of Romme et al. 2003) and a decrease from an $\sim 30 \%-60 \%$ canopy cover (Fig. 28 in Finney et al. 2003) to sparse grasses 8 yr after the fire. Comparison of burned areas with unburned areas for another Colorado fire site with similar vegetation (the 2010 Four Mile Canyon fire) revealed significant losses of organic matter in the top $\sim 3 \mathrm{~cm}$ of the soil (Moody and Nyman 2013). Studies of boreal forests (Viereck 1982; Chambers and Chapin 2002; Chambers et al. 2005; Amiro et al. 2006; Euskirchen et al. 2009; Randerson et al. 2006; Jin et al. 2012) indicate that fire-induced changes in vegetation, soils, and surface organic matter have significant influence on surface properties and thus on energy and water vapor exchanges for several years, including for summer a drastic reduction in surface roughness (and hence atmosphere-surface coupling; Chen and Zhang 2009), increased albedo, lower net radiation, higher surface and soil temperatures, higher soil moisture, a range from similar to smaller sensible heat flux magnitudes, and greater heat flux into and out of the soil.
Similar behavior should be expected in the case that is presented here. For example, Dore et al. (2012) observed significant reduction in net radiation and significant increases in soil temperature and soil heat flux magnitudes $10-15$ years after the fire for a burned ponderosa pine forest in Arizona, when compared with a nearby unaffected forest. As in the case of Hayman, the burned area was devoid of live trees, with only low ground cover. Slow recovery of ponderosa pine forests after severe fires is common (e.g., Roccaforte et al. 2012; Savage and Mast 2005; Strom and Fule 2007). Likewise, Chen and Zhang (2009) used several datasets to show that shorter vegetation reduced atmosphere-surface coupling, which would lower sensible heat flux magnitudes. Cornford (1938), Oke (1987), and LeMone et al. (2003) all reported that reduced ground cover resulted in higher observed surface air temperatures at night.

We focus here on the impact of the fire-induced changes in vegetation and soil through the diurnal cycle by comparing the temperatures at Hayman with those at Manitou. Prefire measurements are unfortunately not available for the Hayman site, and postfire measurements 
are limited to surface and profile temperature, humidity, and wind. Furthermore, we cannot totally attribute the differences between Hayman and Manitou to local fireinduced surface changes, since both sites lie in complex terrain, which can have profound influence on temperatures, especially at night (e.g., Whiteman 2000). Therefore we rely heavily on numerical simulations to explain the observations.

The outline of the paper is as follows. After documenting the observations, weather, and terrain in section 2 , in section 3 we show that Hayman is considerably warmer than Manitou by early morning and that the differences extend upward hundreds of meters. In section 4 , we describe simulations that use the Noah land surface model with multiparameterization (Noah-MP; Niu et al. 2011; Yang et al. 2011a,b; Barlage et al. 2015) coupled to the Advanced Weather Research form of the Weather Research and Forecasting model (ARW-WRF, hereinafter simply referred to as WRF) to replicate the temperature observations and explore the contributions of local surface effects and mesoscale terrain-induced flows. Section 5 is devoted to conclusions and discussion. Additional figures and tables that describe preliminary offline Noah-MP simulations and further details about the WRF results are provided in the online supplemental material.

\section{Observations and data analysis}

\section{a. Data collection}

Intensive observations (NCAR Earth Observing Laboratory 2010a,b,c) at Hayman and Manitou were conducted during two 48-h periods: from 1200 UTC (0500 LST) 12 August to 1100 UTC 14 August, and from 1200 UTC 21 August to 1100 UTC 23 August, with nearsimultaneous radiosonde releases from the two sites at 1-2-h intervals (Fig. 2). In addition, continuous surface $(2 \mathrm{~m})$ observations were collected from a surface tower used as a reference for each radiosonde. Vaisala, Inc., model RS902-SGP radiosondes were used, with Vaisala WXT510 weather sensors for the surface tower. Radiosonde data were collected at a 1-s data rate; surface-tower data were recorded once per second at Manitou and once every $4 \mathrm{~s}$ at Hayman. Comparisons of averages and standard deviations for the full dataset and for every fourth point at Manitou indicated that sampling rate affected neither significantly. Radiosonde temperature-sensor uncertainty is $\sim 0.2 \mathrm{~K}$, with wind speed uncertainty of $\sim 1 \mathrm{~m} \mathrm{~s}^{-1}$. Accuracy for the surface-reference instruments is $\sim 0.2 \mathrm{~K}$ for temperature and $\sim 10^{\circ}-15^{\circ}$ and $1 \mathrm{~m} \mathrm{~s}^{-1}$ for wind direction and speed, respectively.

As can be seen in Fig. 1 (and later below in Fig. 8), two ridges (up to $400 \mathrm{~m}$ higher) separate the two sites. The

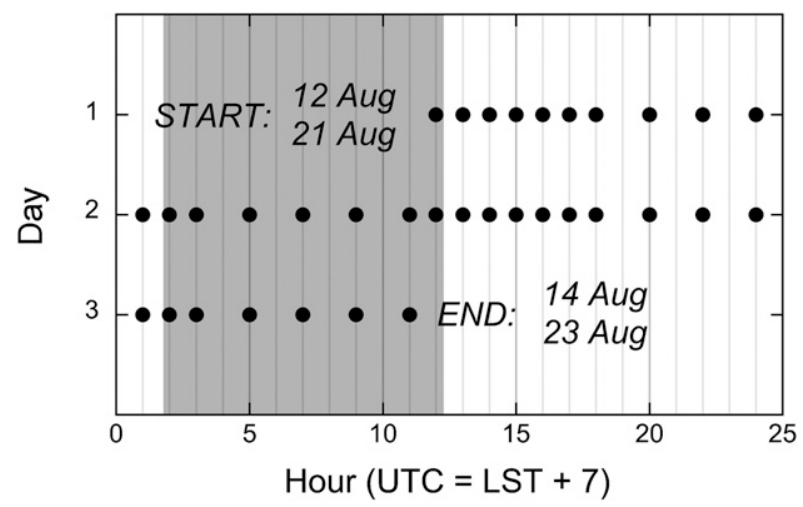

FIG. 2. Radiosonde target release times. The shading indicates the time between sunset and sunrise.

Hayman site lies on a west-facing slope, whereas the Manitou site is $0.5 \mathrm{~km}$ east of and $\sim 34 \mathrm{~m}$ higher than Trout Creek, the base of a nearly north-south valley (aligned roughly from $173^{\circ}$ to $353^{\circ}$ azimuth). The elevations of the two sites differ by $32 \mathrm{~m}$, with Hayman at $2404 \mathrm{~m}^{1}$ and Manitou at $2372 \mathrm{~m}$.

We also used measurements of wind and temperature from the Manitou Experimental Forest Observatory micrometeorological tower (MEFO; NCAR Earth Observing Laboratory 2010d) for comparison with numerical simulations. The MEFO tower (elevation $2385 \mathrm{~m}$ ) is $0.75 \mathrm{~km}$ west of Trout Creek and approximately $45 \mathrm{~m}$ higher; it is only $1.4 \mathrm{~km}$ to the west $\left(258^{\circ}\right)$ and $10-15 \mathrm{~m}$ higher than Manitou. Although these sites are close to one another, the effects of fetch and canopy density on the two sets of measurements can lead to considerable differences (e.g., Belcher et al. 2012). The MEFO site was located to ensure a fetch with trees (Ortega et al. 2014), whereas the Manitou site was located in a more open area to enable releasing radiosondes. These uncertainties will be taken into account in the discussion.

MEFO tower data were collected at five levels (2.04, 7.42, 16.06, 29.9, and 42.86 m), using Campbell Scientific, Inc., model CSAT3 sonic anemometers and NCAR-Vaisala aspirated hygrothermometers, respectively (Ortega et al. 2014). Although transducer shadowing affected the wind measurements (Horst et al. 2015), S. Oncley (NCAR Earth Observing Laboratory, personal communication 2015) suggests a maximum of $3 \%$ error in each wind component, with

\footnotetext{
${ }^{1}$ Note that $15 \mathrm{~m}$ was added to the elevations on the Hayman and Manitou radiosonde headers, which did not include the geoid correction. The corrected elevations match those that are based on the U.S. Geological Survey 7.5-min Mount Deception Quadrangle.
} 
TABLE 1. Winds just before sunrise. Wind direction $\left(^{\circ}\right)$ is to the left of the slash, and wind speed $\left(\mathrm{m} \mathrm{s}^{-1}\right)$ is to the right. For the surface, the standard deviation of the wind speed is given in parentheses. Layer-averaged wind directions are from a vector average; surface wind directions are simply averaged. The wind direction is such that $360^{\circ}-0^{\circ}$ shifts are not a factor.

\begin{tabular}{cllllllcr}
\hline \hline & \multicolumn{2}{c}{ Avg in lowest 1 km } & & \multicolumn{2}{c}{ Avg in lowest 500 m } & & \multicolumn{2}{c}{ 1-h avg at surface } \\
\cline { 2 - 3 } Date and time (UTC) & Hayman & Manitou & & Hayman & Manitou & & Hayman & Manitou \\
\hline 1200 13 Aug & $238 / 3.45$ & $243 / 5.07$ & & $192 / 2.23$ & $195 / 4.16$ & & $149 / 1.73(0.70)$ & $163 / 0.98(0.44)$ \\
110014 Aug & $218 / 4.86$ & $233 / 3.12$ & & $218 / 3.97$ & $193 / 5.09$ & & $195 / 0.54(0.48)$ & $166 / 0.53(0.24)$ \\
120021 Aug & $202 / 8.47$ & $196 / 7.22$ & & $211 / 6.40$ & $186 / 4.72$ & & $172 / 2.48(0.24)$ & $159 / 0.74(0.36)$ \\
120022 Aug & $234 / 6.05$ & $237 / 6.05$ & & $212 / 5.76$ & $220 / 4.90$ & & $190 / 2.72(0.42)$ & $146 / 0.91(0.35)$ \\
\hline
\end{tabular}

temperature error of the same order as that for the radiosonde surface stations.

The weather was mostly fair during the two observing periods, with winds weak for the nights analyzed (Table 1). Although there were weak showers on 12 August, only decaying convection was in the area by 0000 UTC 13 August. GOES-13 satellite images show that skies were virtually clear on most of 13 and14 August, as well as during the presunrise hours of 21 and 22 August. On the other hand, images reveal scattered-to-broken cumulus clouds developing during the day on 21 and 22 August, with maximum tops at $\sim 263 \mathrm{~K}(3500-4500 \mathrm{~m}$ above Hayman and Manitou, or 5900-6900 m MSL on the basis of the soundings). Middle clouds started to increase above the decaying cumulus around 2300 UTC 22 August. The soils were drying out during the observation period, after heavy rains (peak stage- 4 precipitation of $60 \mathrm{~mm}$ at Manitou and $40 \mathrm{~mm}$ at Hayman) between 5 and 10 August (NCEP Climate Prediction Center and UCAR Joint Office for Science Support 2000).

The nighttime boundary layers for Hayman and Manitou are far more isolated from each other than the daytime boundary layers. The nighttime Hayman balloon trajectories travel only short distances in the lowest $500 \mathrm{~m}$. From an average wind of $5 \mathrm{~m} \mathrm{~s}^{-1}$ and a balloon rise rate of $3 \mathrm{~m} \mathrm{~s}^{-1}$ this distance would be $833 \mathrm{~m}$; the actual distances in online supplemental Fig. S1 of $\sim 500 \mathrm{~m}$ or less are consistent with a faster balloon rise rate. This is consistent with measurements only west of the eastern 100-300+-m ridge that separates Hayman from Manitou (Figs. 1 and 8, described below). In a similar way, the Manitou measurements remain to the east of the ridge. Given the wind directions in Table 1, the stable stratification, and likely weak turbulence, there was likely little horizontal exchange across the ridge. During the day (PBL depth $<3.5-4 \mathrm{~km}$; Figs. $5-7$, described in more detail below), the Hayman radiosonde trajectories remain over the burn area while they are sampling boundary layer air and the Manitou trajectories remain over unburned terrain (Fig. S1). The air engulfed into both boundary layers growing during the day likely originates from far upstream, however, and thus is unaffected by the burn area. Also, since the PBL depths every day were much higher than the intervening terrain and since radiosonde trajectories remained within $15 \mathrm{~km}$ of each other, horizontal mixing of the two PBLs by convectively driven large eddies was likely. Thus, we expect less difference during the day.

\section{b. Data analysis}

Temperatures for each sounding were averaged into 5-hPa intervals after replacement of missing data with interpolated values. The smoothed soundings were then interpolated to common heights and then in time to correspond to nominal sounding times (since sounding times did not always correspond to those in Fig. 2, and some soundings were missing or unusable). The resulting temperature profiles were adjusted for adiabatic lapse rate using pressure altitude (above ground level, or AGL) to facilitate comparison with surface temperatures and to more clearly display site differences and time evolution. The PBL depth was subjectively identified as the base of the first height interval exceeding the $2 \mathrm{~K} \mathrm{~km}^{-1}$ threshold (for the vertical potential-temperature gradient) of LeMone et al. (2013, hereinafter L2013), which was based on model profiles with roughly similar vertical spacing.

\section{Observational results}

\section{a. Near the surface}

Figure 3 shows that the 2-m temperatures at Hayman are between 4 and $7 \mathrm{~K}$ higher than those at Manitou on all four mornings. The temperatures at the two sites converge during the day, becoming nearly equal around local noon (1800-2000 UTC) on 13 August and by midmorning (1600 UTC or 0900 LST) on 21-22 August. Hayman remains slightly warmer than Manitou on 21-22 August, however, in part because of slightly fewer clouds. Note that these differences are in contrast to the recent paper by Alkama and Cescatti (2016), in which satellite and climatological surface observations were used to find significantly warmer maximum temperatures and similar minimum temperatures for deforested areas relative to nearby forested areas. 

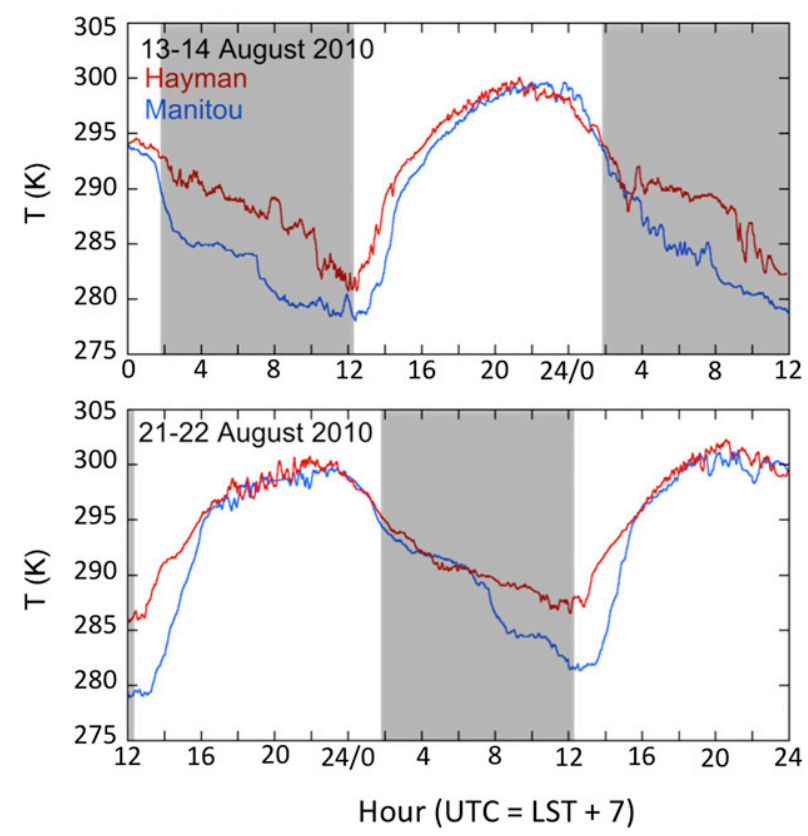

FIG. 3. The 2-m air temperatures at Hayman and Manitou for fair-weather portions of the two intensive observing periods. Times between sunset and sunrise are shaded.

Local fire-induced surface changes likely contribute to keeping Hayman's nighttime temperatures warmer than Manitou, but mountain-valley flows should be a factor as well. Figure 4 shows the nighttime $2-\mathrm{m}$ wind speed, wind direction (found from the half-hour averaged components), and temperature for the three cool-down periods. From Fig. 1, the wind direction at Manitou is consistent with down-valley winds, which are associated with cooler air (e.g., Whiteman 2000), with occasional easterly excursions between 0700 and 1000 UTC (0000-0300 LST). On all three nights, the coolest temperatures are mostly associated with near-calm winds, consistent with reduced downward mixing of warmer air and nocturnal cold-air pooling.

The Hayman observations were taken from the western slope of a hill with a peak that is located about $400 \mathrm{~m}$ higher and between 3 and $4 \mathrm{~km}$ to the east (Fig. 1), which would suggest terrain-induced east winds according to Whiteman (2000). The Hayman winds in Fig. 4 are mostly from the south and roughly parallel to the contours, however, with few easterly-wind events. Thus a simple link of the wind direction to the local terrain is not evident, although Hayman lies in a larger-scale north-northeast-south-southwest valley (Fig. 8, below). Moreover, the early-morning balloon trajectories in Fig. S1 indicate average southerly winds in the lowest $200-500 \mathrm{~m}$.

\section{b. Boundary layer}

The temperature profiles for the three warming sequences, adjusted for the adiabatic lapse rate, appear for Hayman and Manitou in Fig. 5. In all cases, the PBL at

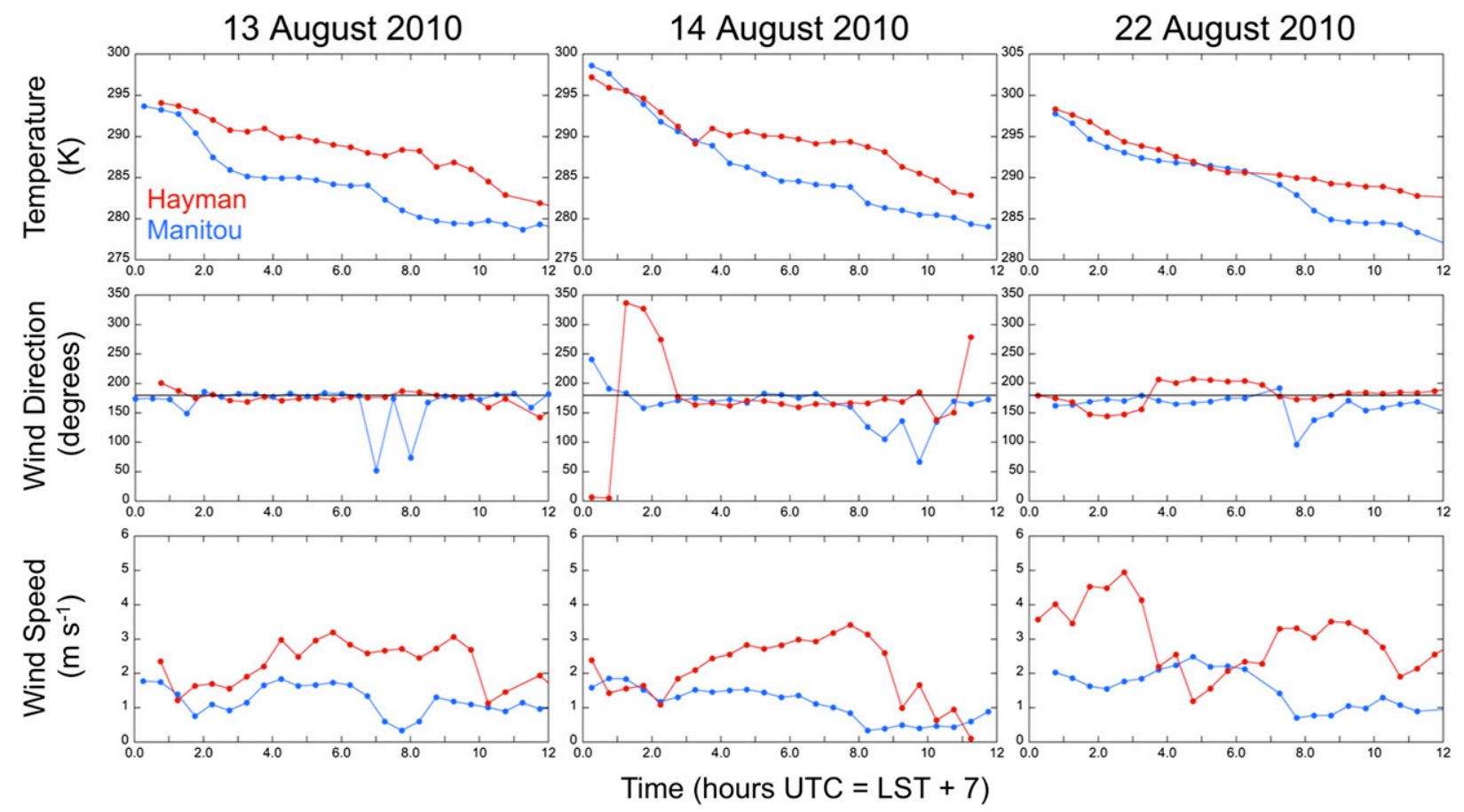

FIG. 4. The 2-m air temperature and winds for the cooldown periods of Fig. 3. 

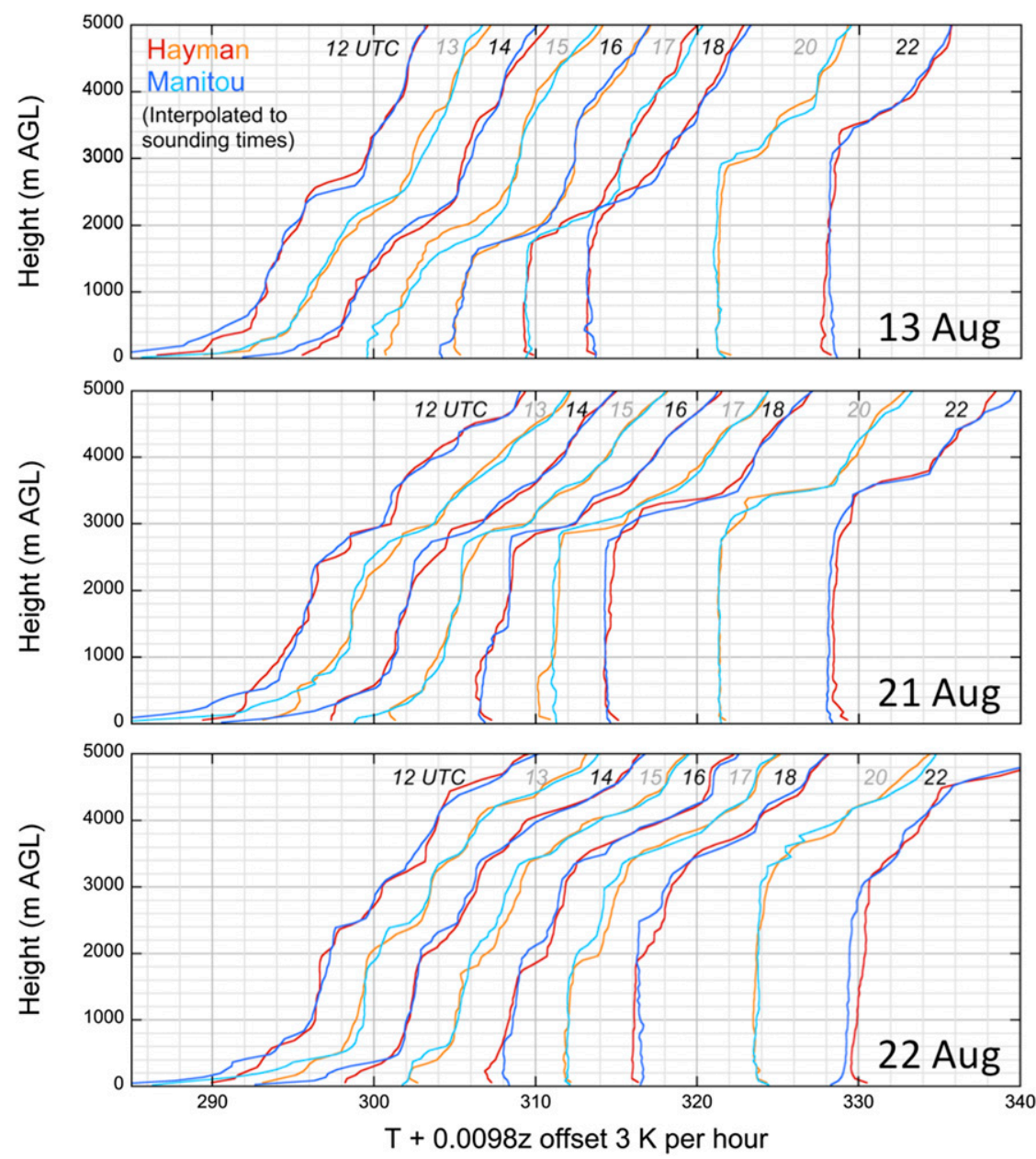

FIG. 5. Warming sounding sequences for 13, 21, and 22 Aug, averaged over 5-hPa layers and then interpolated to the indicated times. For ease in distinguishing the two sites, the temperatures are corrected for the adiabatic lapse rate. The height $z$ above ground level is relative to Manitou.

Hayman starts out at sunrise as warmer and much less stable than Manitou, with the two sets of soundings becoming more similar during the day. As can be seen from Fig. 6, this behavior is particularly obvious when the early-morning and early-afternoon soundings are averaged.

In Fig. 7, the average daytime PBL depths at Manitou are greater than at Hayman between approximately 1600 and 2000 UTC (0900-1300 LST) and are about the same afterward. The earlier more rapid growth at Manitou is consistent with the expected greater sensible heat fluxes, given the stronger coupling and smaller albedo for evergreen trees than for grasses (Table 3, described in more detail below; see also Table S1 in the online supplemental material), whereas similar PBL depths at the two locations later in the day are consistent with horizontal mixing of air influenced by different surface fluxes over the long fetch associated with PBL depth (e.g., Reen et al. 2006).

\section{WRF setup and numerical experiments}

\section{a. Model setup}

We have established that there are considerable differences between the temperatures at Hayman and Manitou during the night and that they become small during the day. WRF simulations enable us to examine how local fire-induced surface modifications and mesoscale terrain-induced flows contribute to these changes. We start with two runs using WRF, version 3.6 (v3.6): a "Fire" run that represents vegetation/soil changes resulting from the 2002 Hayman fire and a "No Fire" run that incorporates the vegetation and soil properties if those changes had never happened. 

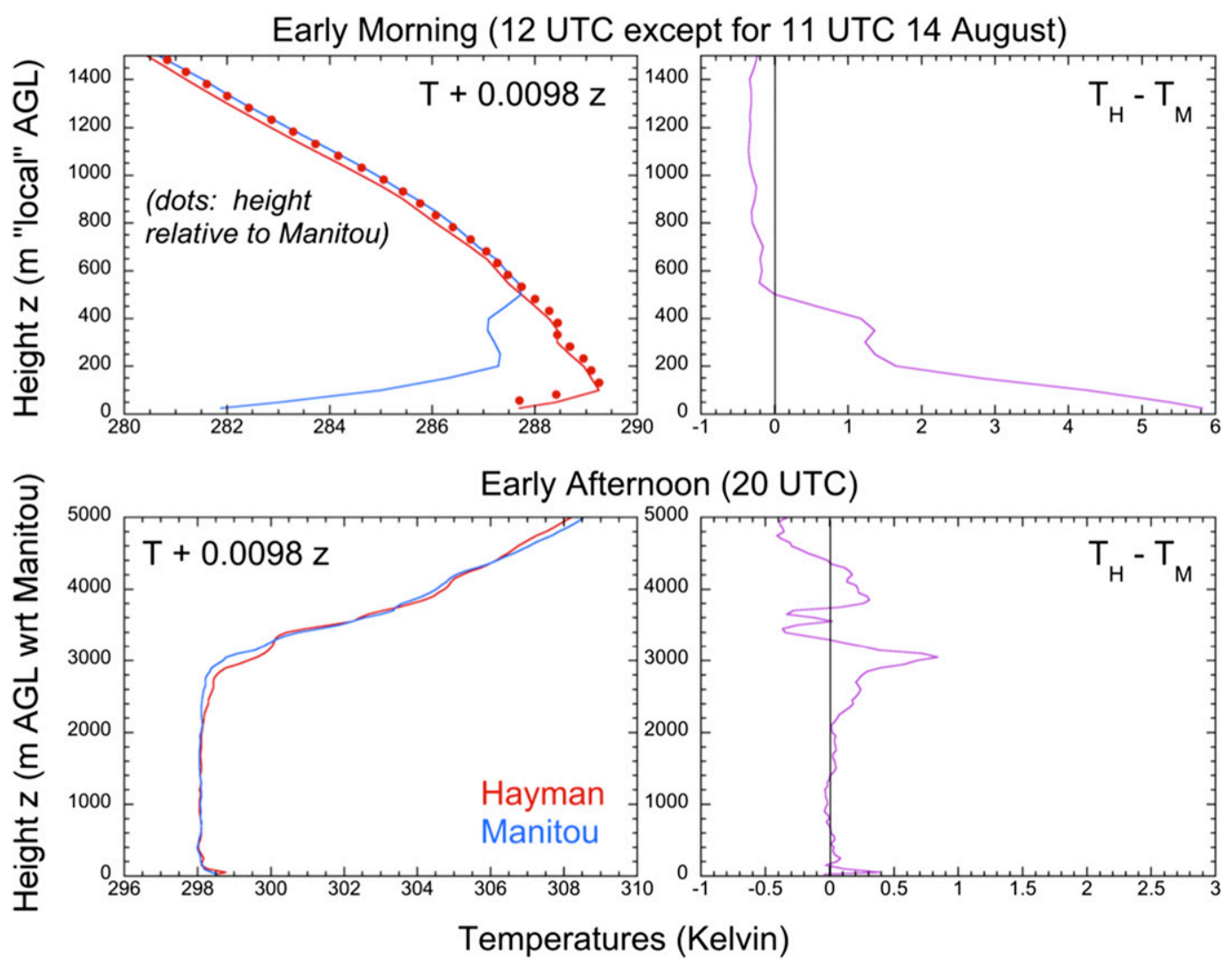

FIG. 6. For early morning (1200 UTC 13, 21, and 22 Aug; 1100 UTC 14 Aug) and early afternoon (2000 UTC 13, 21, and $22 \mathrm{Aug}$ ), (left) average height-adjusted temperature profiles and (right) differences between the profiles. Height $z$ (AGL) is defined according to the sounding origin for early-morning soundings and relative to Manitou for the early afternoon and for the dotted early-morning sounding.

The setup for the WRF simulations is summarized in Fig. 8 and Table 2. Domains 1-4 going inward have horizontal grid spacings of $13.5,4.5,1.5$, and $0.5 \mathrm{~km}$. There are 50 vertical layers in the Fire and No Fire runs, with the lowest grid level around $27.6 \mathrm{~m}$ (vertical spacing at the lower levels is illustrated in the 2200 UTC sounding in Fig. 12, described below). There is two-way nesting between the outer two domains (1 and 2) but one-way nesting between the inner three domains (2 and 3; 3 and 4) to keep the outer domains similar for the Fire and No Fire runs. Lateral boundary conditions are from the NOAA/NCEP (2000) Final Analysis (FNL) data, available every $6 \mathrm{~h}$ at $1^{\circ}$ resolution. The WRF runs extend from 0000 UTC 20 August to 0000 UTC 23 August, ${ }^{2}$ with initial surface and soil conditions from two sets of 3-yr offline Noah-MP spinup runs.

\footnotetext{
${ }^{2}$ We simulate only the second period of observations, which has the benefit of simpler initial conditions (there was rainfall at the beginning of the first period).
}

Vegetation and soil characteristics for the Fire and No Fire runs are summarized in Fig. 8 and Table 3; we use the default soils, which were mostly sandy loam (the Manitou soil type) or loamy sand (the Hayman soil type) in and

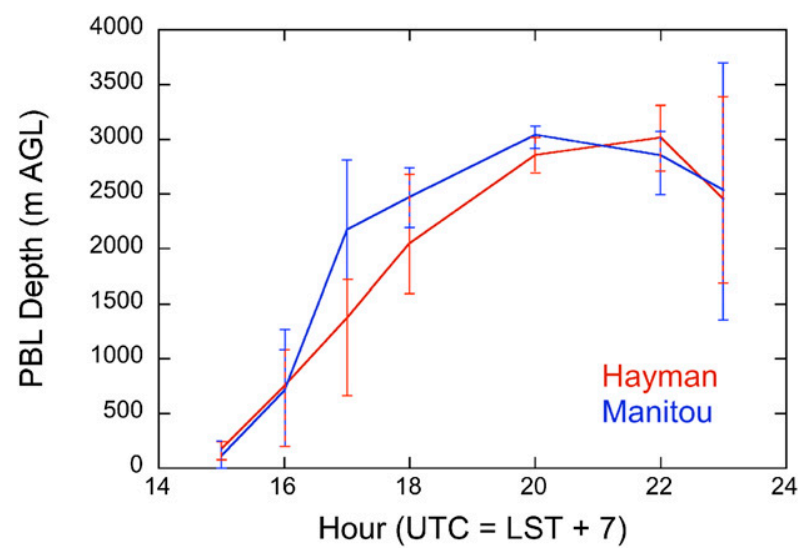

FIG. 7. For the three days in Fig. 5, average objectively determined PBL depths found by applying the L2013 criterion to 13, 21, and 22 Aug. Error bars indicate ranges for each site. Height above ground level is found by subtracting $2357 \mathrm{~m}$ for Manitou and $2389 \mathrm{~m}$ for Hayman. 

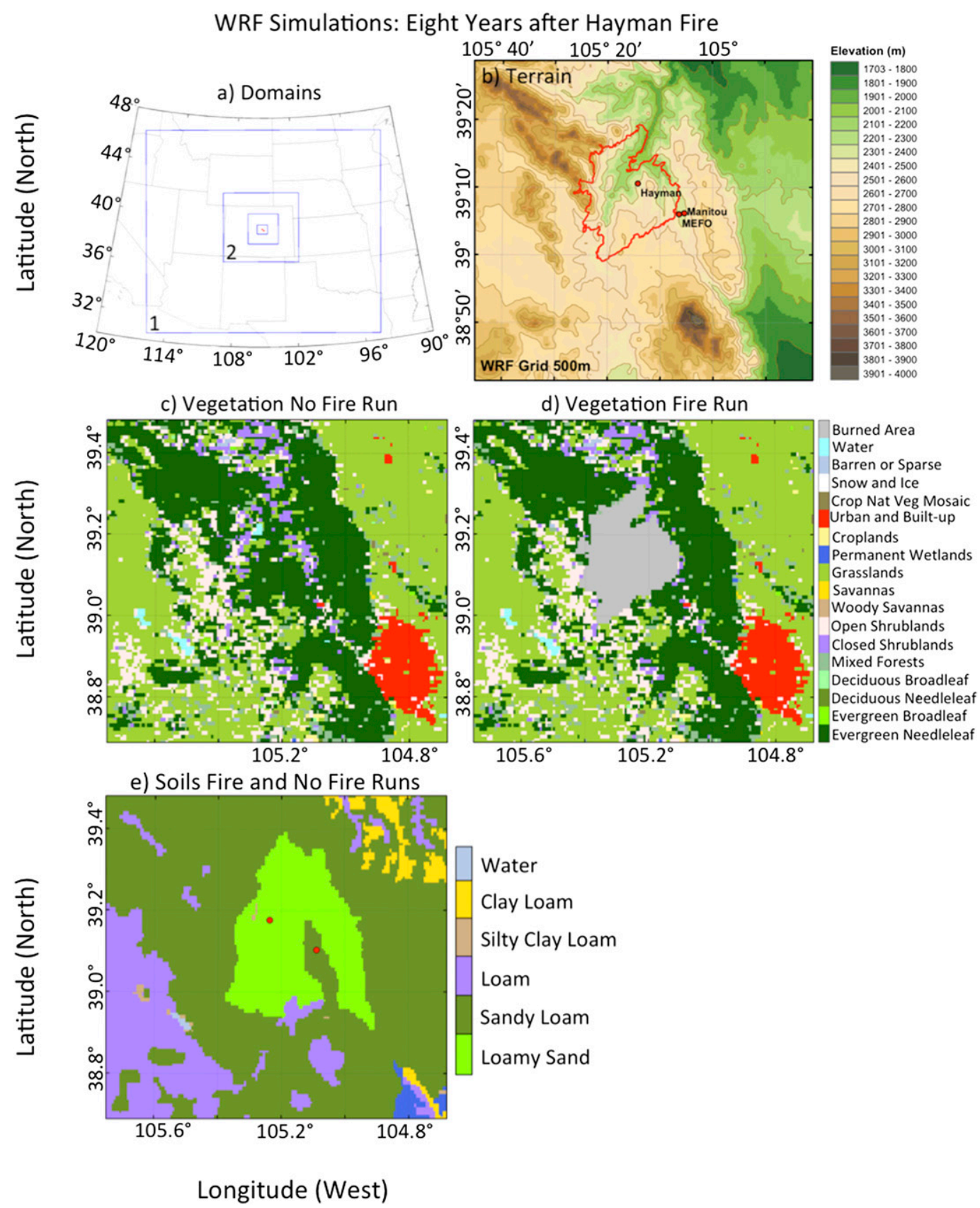

FIG. 8. The setup for WRF simulations: (a) the domains (the smallest unmarked domain is domain 4, and the next-smallest domain is domain 3), (b) the domain-4 terrain, domain-4 vegetation for the (c) No Fire and (d) Fire runs, and (e) domain-4 soils for both Fire and No Fire runs (note, however, that the top $10 \mathrm{~cm}$ of soil is "organic" if the vegetation type is evergreen needleleaf).

around the fire scar. On the basis of the results of the offline Noah-MP simulations, which was chosen because of more freedom to change vegetation parameters (the details are given in online supplemental Figs. S2-S4 and Table S1; Moore 1992; Mesinger et al. 2006), we replace the top $10 \mathrm{~cm}$ of soil with organic matter when the vegetation is evergreen needleleaf to represent leaf litter and organic material in the soil. The properties of this organic matter are from Lawrence and Slater (2008).

Vegetation in the fire scar is set to grassland for the Fire run, whereas the default vegetation (mostly evergreen needleleaf) is used for the No Fire run. Some parameters for grassland and evergreen needleleaf vegetation in Table 3 are modified to be more consistent with 
TABLE 2. The WRF model physics schemes that were used.

\begin{tabular}{ll}
\hline \multicolumn{1}{c}{ Process } & \multicolumn{1}{c}{ Parameterization } \\
\hline $\begin{array}{l}\text { PBL scheme } \\
\text { Land surface }\end{array}$ & $\begin{array}{l}\text { Yonsei University (YSU; Hong et al. 2006) } \\
\text { Noah-MP (Niu et al. 2011) with radiation option 3 (vertical; see section 4b) and vegetation option 4 (constant } \\
\text { vegetation fraction; seasonal variation through monthly LAI) } \\
\text { Ropid Radiative Transfer Model (Mlawer et al. 1997) }\end{array}$ \\
$\begin{array}{l}\text { Shortwave radiation } \\
\text { Microphysics }\end{array}$ & Dudhia (1989) \\
Cumulus scheme & WRF single-moment three-class (WSM3; Hong et al. 2004) \\
\hline
\end{tabular}

the shorter grasses and trees observed in the HaymanManitou area (D. Gochis 2014, personal communication). These modifications are applied to all grid points with those vegetation types. The vegetation types for the No Fire run and for the fire run outside the fire scar are shown in Fig. 8. Default WRF parameters are used for vegetation types other than grass and evergreen needleleaf, with type-specific constant vegetation fraction that is based on pre-2002 AVHRR data and monthly leaf area index (LAI) that is based on 2010 MODIS data.

An important aspect of nighttime terrain-induced flows is cold pooling, which is difficult to capture in mesoscale models but likely contributes to the very cool Manitou nighttime temperatures. Therefore, additional Fire runs were conducted with horizontal instead of terrain-following (i.e., grid-layer-following) diffusion
$(\mathrm{F}+\mathrm{HD})$, with vertical resolution enhanced by adding a new grid layer at $12.5 \mathrm{~m}(\sim 10 \mathrm{~m}$; hence $\mathrm{F}+10 \mathrm{~m})$, and with both modifications $(\mathrm{F}+\mathrm{HD}+10 \mathrm{~m})$, as recommended by Zangl $(2002,2005)$ and Billings et al. (2006) for better capture of cold-air pooling. For the " $+10 \mathrm{~m}$ " runs the second grid layer is at $\sim 37.85 \mathrm{~m}$, with the remaining grid layers at heights similar to the other runs. Because model code limitations in WRF v3.6 precluded a successful $\mathrm{F}+\mathrm{HD}+10 \mathrm{~m}$ run, $\mathrm{F}+\mathrm{HD}-3.6 .1$ and $\mathrm{F}+\mathrm{HD}+10 \mathrm{~m}-3.6 .1$ were both run using WRF v3.6.1. The runs are listed in Table 4.

\section{b. Comparisons between Fire and No Fire runs}

Figure 9 shows the Fire and No Fire maps of the diagnosed Noah-MP 2-m temperature T2M for late afternoon and early morning. Whereas the effective height of $\mathrm{T} 2 \mathrm{M}$ for grassland is just over $2 \mathrm{~m}$, those for evergreen

TABLE 3. The land surface parameters used for the WRF spinup and actual runs (also see Fig. 8).

\begin{tabular}{|c|c|c|}
\hline Parameter & Inside fire scar for Fire runs & Outside fire scar for Fire runs; all points for No Fire run \\
\hline Soil type & $\begin{array}{l}\text { Default soil (Fig. 8; for Hayman, the default soil is } \\
\text { loamy sand) }\end{array}$ & 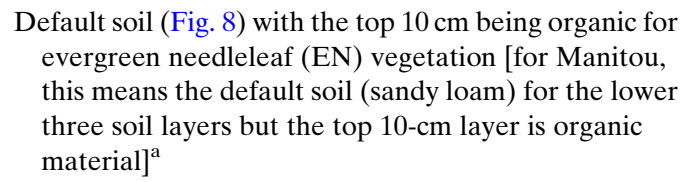 \\
\hline Vegetation type & Grassland & MODIS categories ( $=$ EN for Manitou) \\
\hline Vegetation fraction & 0.344 & WRF map, as based on 0.144-deg AVHRR \\
\hline LAI (monthly) & $\begin{array}{l}\text { Monthly values are extracted from } 2010 \text { 1-km 8-day } \\
\text { MODIS values for Hayman }{ }^{\mathrm{b}} \text { ( } 0.678 \text { for August) }\end{array}$ & $\begin{array}{l}\text { Default monthly values, except for EN, which is } \\
\text { assigned Manitou values }{ }^{\mathrm{b}} \text { ( } 1.829 \text { for August) and } \\
\text { grass, which is assigned Hayman values }\end{array}$ \\
\hline Canopy height & $0.2 \mathrm{~m}($ default $=1 \mathrm{~m})$ & $\begin{array}{l}\text { Default except } 10 \mathrm{~m} \text { for EN (instead of } 20-\mathrm{m} \text { default) } \\
\text { and } 0.2 \mathrm{~m} \text { for grass }\end{array}$ \\
\hline "NROOT" & 2 (roots down to $0.40 \mathrm{~m}$ ) & Default except NROOT $=2$ for grass \\
\hline $\begin{array}{l}\text { "ZOM" (surface } \\
\text { roughness length) }\end{array}$ & $0.024 \mathrm{~m}($ default $=0.12 \mathrm{~m})$ & $\begin{array}{l}\text { Default except } 0.545 \mathrm{~m}(\text { default }=1.09 \mathrm{~m}) \text { for } \mathrm{EN} \text { and } \\
0.024 \text { for grass }\end{array}$ \\
\hline Albedo $^{c}$ & $\begin{array}{l}\text { Calculated; the avg daily range for the coupled Fire } \\
\text { run is } 0.2024-0.2549\end{array}$ & $\begin{array}{l}\text { Calculated; for EN, the avg daily range for the coupled } \\
\text { Fire run is } 0.1201-0.1487\end{array}$ \\
\hline
\end{tabular}

\footnotetext{
${ }^{a}$ The organic properties are from Lawrence and Slater (2008).

${ }^{\mathrm{b}}$ Evergreen needleleaf and grassland are assigned LAI values extracted from 2010 1-km 8-day MODIS values for Manitou and Hayman; see https://lpdaac.usgs.gov/dataset_discovery/modis/modis_products_table/mcd15a2.

${ }^{\mathrm{c}}$ Albedo in Noah-MP is independent of soil type, and therefore organic layer does not affect albedo. Albedo is a weighted average of vegetation albedo and soil albedo, which varies with soil moisture [the default range for visible (near infrared) radiation is 0.09-0.18 (0.18-0.36), with lower numbers for wetter soils]. See Yang et al. (2011a, pp. 9-10) for details.
} 
TABLE 4. WRF simulations.

\begin{tabular}{|c|c|c|}
\hline Run & Description & WRF version \\
\hline No Fire (or NF) & $\begin{array}{l}\text { Vegetation and soils as if no fire had occurred; organic matter added to soil for EN } \\
\text { vegetation (see Table } 3 \text { ) }\end{array}$ & 3.6 \\
\hline Fire (or F) & Vegetation in fire scar modified to grassland; soil has no organic material (see Table 3) & 3.6 \\
\hline $\mathrm{F}+\mathrm{HD}-3.6$ & Horizontal diffusion option added & 3.6 \\
\hline $\mathrm{F}+10 \mathrm{~m}-3.6$ & Grid layer added at $12.5 \mathrm{~m} \mathrm{AGL}$; second grid layer raised by $\sim 10 \mathrm{~m}$ & 3.6 \\
\hline $\mathrm{F}+\mathrm{HD}-3.6 .1$ & Horizontal diffusion option added & 3.6 .1 \\
\hline $\mathrm{F}+\mathrm{HD}+10 \mathrm{~m}-3.6 .1$ & Horizontal diffusion and $12.5-\mathrm{m}$ grid layer added & 3.6.1 \\
\hline
\end{tabular}

needleleaf at Manitou and Hayman are $5.8 \mathrm{~m}$ and $5.7 \mathrm{~m}$, respectively. ${ }^{3}$ With this in mind, we see that the daytime temperatures and the nighttime temperatures outside the fire scar from the two runs are almost indistinguishable. The nighttime temperatures within the fire scar show considerable differences, however. For the Fire run, the temperatures in the fire scar (which has grass and no organic layer) are warmer, with much more turquoise-togreen color $(\sim 285-287 \mathrm{~K})$ in the figure than for the No Fire run (mostly evergreen needleleaf forest with a $10-\mathrm{cm}$ layer of decaying vegetation), which has more blue shades evident (280-282 K).

Figure 10 compares the Fire and No Fire diagnosed 2-m temperature T2M with observations at Manitou and Hayman along with a new diagnostic temperature $\mathrm{T} 2 \mathrm{M}_{\text {under, }}$ which has an effective height of two meters. We start with the 2-m temperature under the canopy ( $\left.\mathrm{T} 2 \mathrm{~V}_{\text {under }}\right)$, which is found from the canopy air temperature TAH and the surface temperature TGV by following the method of Niu and Yang (2004), and using the resistances $r_{\text {ah }}$ for layer 1 between roughness length $z_{0}$ and $2 \mathrm{~m}$ and for layer 2 between 2 and $6.5 \mathrm{~m}$ :

$$
\mathrm{T} 2 \mathrm{~V}_{\text {under }}=\frac{r_{\mathrm{ah} 1} \mathrm{TAH}+r_{\mathrm{ah} 2} \mathrm{TGV}}{r_{\mathrm{ah} 1}+r_{\mathrm{ah} 2}} .
$$

The temperature $\mathrm{T} 2 \mathrm{M}_{\text {under }}$ can then be found from the weighted average:

$$
\mathrm{T}_{2} \mathrm{M}_{\text {under }}=f \mathrm{~T} 2 \mathrm{~V}_{\text {under }}+(1-f) \mathrm{T} 2 \mathrm{~B},
$$

where $\mathrm{T} 2 \mathrm{~B}$ is the 2-m temperature above bare ground and $f$ is the vegetation fraction. This calculation was not necessary for grassland.

In Fig. 10, T2M values for the Fire run are mostly within $1 \mathrm{~K}$ of the observed temperature at Hayman through the

\footnotetext{
${ }^{3}$ These values are vegetation-fraction-weighted averages of $9.045 \mathrm{~m}$ for the canopy $(2 \mathrm{~m}+$ canopy displacement height of $6.5 \mathrm{~m}+$ roughness length $z_{0}=0.545 \mathrm{~m}$ ) and $2.01 \mathrm{~m}$ for bare ground $\left(2 \mathrm{~m}+z_{0}=0.01 \mathrm{~m}\right)$, where vegetation fraction $f=0.5456$ for Manitou and 0.5257 for Hayman for the No Fire run.
}

diurnal cycle and are also within $1 \mathrm{~K}$ of the observed daytime temperatures after 1600 UTC at Hayman, Manitou, and the MEFO micrometeorological tower Also, T2M follows the observed temperature well into the night of 22 August at Manitou and the MEFO tower, despite the 1.4-km horizontal separation between the two locations (T2M at MEFO is also close to that at Manitou; online supplemental Fig. S7). The impact of soil and land-cover changes is reflected by the nighttime surface air temperatures at Hayman for the Fire run being 3-5 K warmer than for the No Fire run. On the other hand, nighttime T2M values for the No Fire run are often warmer at Manitou than at Hayman. This result, along with observed 2-m temperatures being up to $7 \mathrm{~K}$ cooler than modeled values at Manitou, supports our suspicion that WRF has failed to simulate cold-air pooling.

Use of $\mathrm{T}_{2} \mathrm{M}_{\text {under }}$ leads to a $1-2-\mathrm{K}$ improvement in the modeled nighttime temperatures in the presunrise hours of 21 August at Manitou but leads to only a slight improvement in other nighttime temperatures. As expected, Fire and No Fire temperatures are nearly identical at Manitou, except for some afternoon excursions due to clouds, which were observed on both 21 and 22 August and are reflected in the modeled surface energy budget in Fig. 11 for 22 August. Note that $\mathrm{T}_{2} \mathrm{M}_{\text {under }}$ is too warm during the day at both locations for the Fire run. This situation is due to large values of the surface temperature beneath the evergreen needleleaf trees (TGV), which actually exceeds the bare-ground surface temperature (TGB). This curious behavior has its origins in the treatment of downwelling solar radiation under Noah-MP radiation option 3, which assumes that solar radiation comes straight down through the canopy. Solar absorption at the ground (SAG) beneath the vegetation is reduced by absorption by the canopy overhead, relative to the absorption on the bare ground. In the calculation of the energy budget beneath the canopy, however, SAG is set equal to the weighted average of the canopy and bareground values, as a way of partially accounting for sunlight coming in from the sides of the vegetated portion of the grid square. Because the surface beneath the canopy loses less IR energy to space than does the bare ground, daytime TGV ends up larger than TGB. During the night, TGV does not 


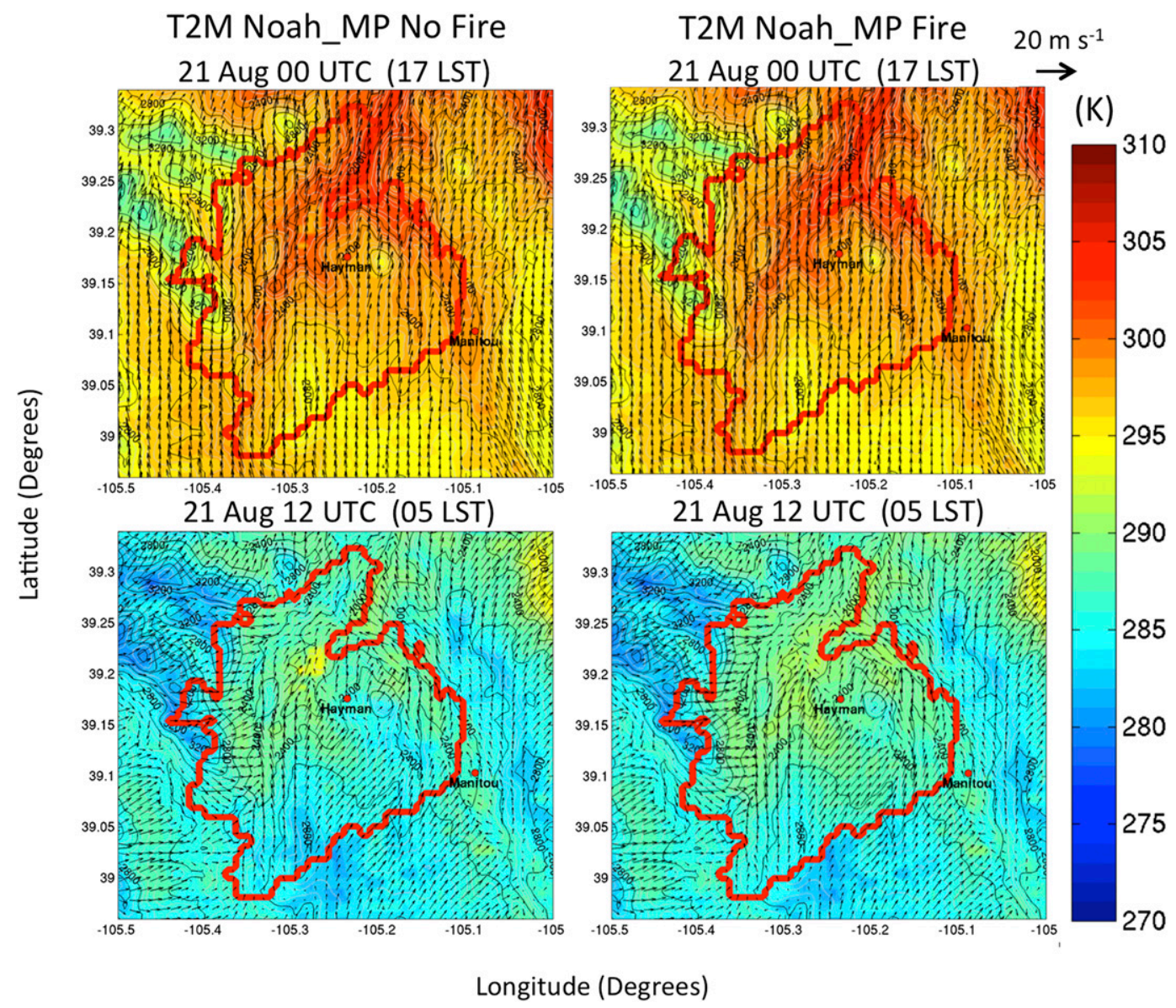

FIG. 9. For 21 Aug, maps of Noah-MP temperature T2M for (top) late afternoon and (bottom) early morning before sunrise for the (left) No Fire and (right) Fire runs; $10-\mathrm{m}$ wind speed vectors are included, and the fire scar is outlined in red.

have this problem, since the surface energy budgets for vegetation and bare ground are handled separately.

Fire-induced changes in the Hayman surface energy budget (Fig. 11) are consistent with daytime summer measurements in areas where more shallow vegetation has replaced forest as a result of fire. From the figure, the $R_{\text {net }}$ change going from No Fire (evergreen needleleaf) to Fire (grass) is consistent with the increased albedo for the postfire replacement of forest by shallow vegetation or sparser, younger trees that was observed by Amiro et al. (2006; 10 yr after the burn) for forest; by Chambers and Chapin (2002; first decade), Jin et al. (2012; 5 yr), and Liu and Randerson (2008; 4 yr) for boreal forests; and by Dore et al. (2012; 10-14 yr) for a ponderosa pine forest.

In a similar way, reduced sensible heat flux $(\mathrm{SH})$ and latent heat flux $(\mathrm{LH})$ at Hayman for the Fire run relative to Hayman No Fire values and Manitou Fire values (which are nearly identical to the Manitou No Fire values), are consistent with the expected weaker coupling (Chen and Zhang 2009) and higher albedo associated with grass. Lower $\mathrm{SH}$ in a postfire environment is consistent with observations over fire-succeeding shallow vegetation that were documented in Chambers and Chapin (2002), Liu and Randerson (2008), and Liu et al. (2005; 3 and $15 \mathrm{yr}$ ). Reduced LH is similarly consistent with changes over summertime boreal-forest grasses in a 3-yr-old burn scar, as documented by Liu and Randerson (2008) and Liu et al. (2005), relative to nearby unaffected forest. Also, loss of the insulating effect of the organic layer increases the diurnal amplitude of the heat flux into the soil $G_{\text {sfc }}$, consistent with the postfire changes observed by Chambers and Chapin (2002), Dore et al. (2012), Liu and Randerson (2008), and Liu et al. (2005).

In comparing the nighttime fluxes and temperature at Hayman for the Fire and No Fire runs in Fig. 10, it is clear that the warming effects of heat flow from the uninsulated (no organic matter) soil more than compensate for less downward heat flux at Hayman with a grassy surface. This is confirmed in the offline Noah-MP runs (Fig. S4), which show the warming effect of going from insulated 

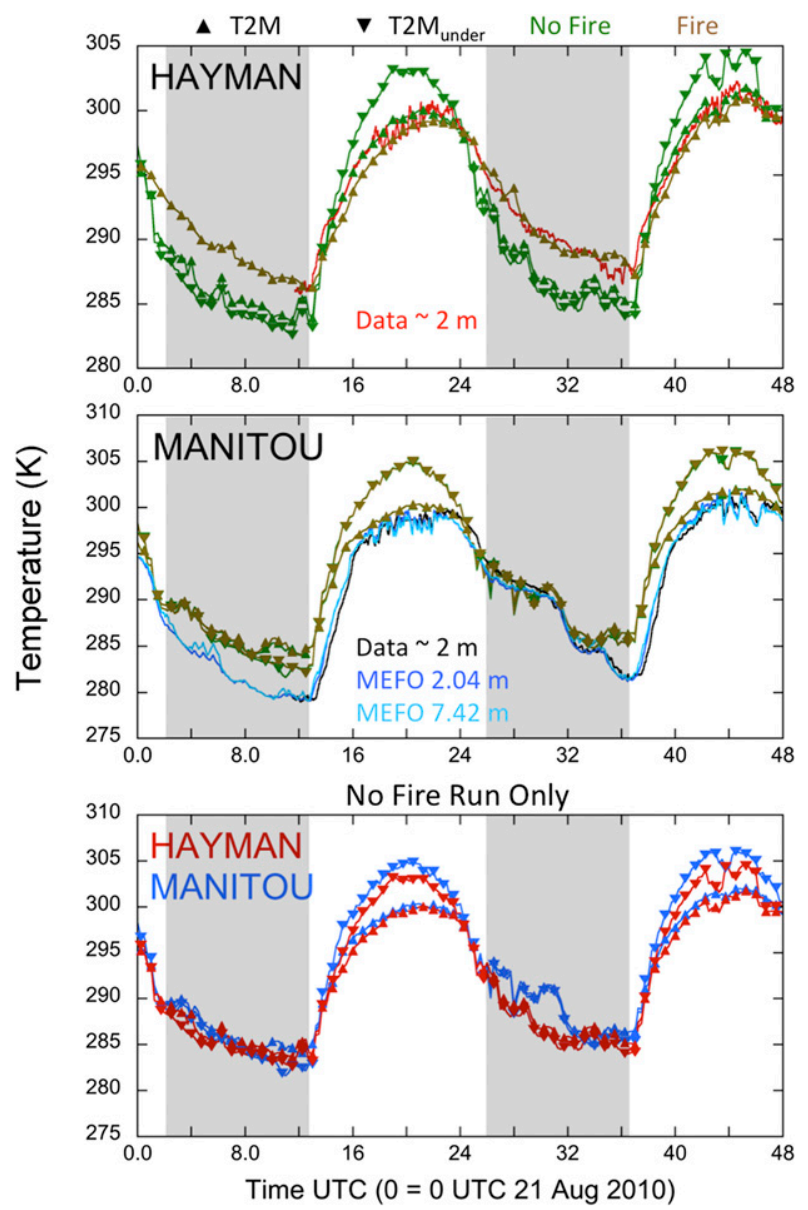

FIG. 10. Comparison of 2-m temperatures from the Fire and No Fire runs with observations. For (top) for Hayman and (middle) Manitou, green is the No Fire run and brown is the Fire run; (bottom) results for the No Fire run are highlighted for both sites. For all panels, T2M and $\mathrm{T} 2 \mathrm{M}_{\text {under }}$ are shown by upward-pointing and downward-pointing triangles, respectively. For grass, $\mathrm{T}_{2} \mathrm{M}_{\mathrm{under}}$ is set equal to T2M. Times from sunset to sunrise are shaded. Note that the $y$ axis for the top panel stops at $305 \mathrm{~K}$.

to uninsulated soil is 4 times that of the cooling effect of replacing evergreen needleleaf vegetation with grass.

As previously noted, Alkama and Cescatti (2016) found near-identical nighttime surface air temperatures and much warmer daytime temperatures over deforested areas when compared with nearby forested areas. One potential source of the nighttime discrepancy between the two studies is the warming that is due to loss of surface and soil organic matter as a result of fire in our case, which more than compensates for the cooling that is due to reduced downward sensible heat flux in the presence of shorter vegetation. While such loss of organic matter is associated with deforestation by severe burns (Table 2 in Romme et al. 2003), it does not necessarily occur with deforestation from other causes or less severe fires. Why do they see a significant difference in the daytime when we do not? As discussed in the foregoing, our daytime similarity in temperature is likely related to the short distance between Hayman and Manitouonly a few boundary layer depths apart during the afternoon.

Model profiles of height-adjusted temperature at Hayman in Fig. 12 show that near-sunrise (1200 and 1300 UTC) differences between the Fire and No Fire runs are concentrated near the surface. Once the sun rises, the No Fire PBL warms faster, but the Fire and No Fire profiles are almost identical by $\sim 1800-2000$ UTC. Reflecting the vertical grid spacing, the modeled soundings are too smooth, failing to capture the multiple stable layers in the observed soundings. Model-observation differences likely also result from the horizontal separation between the vertical model profiles and the slanted profiles from radiosondes, which are $\sim 5-10 \mathrm{~km}$ to the east of their launch location by the time they reach $5 \mathrm{~km}$ AGL (Fig. S1). Especially by the third day of simulation (initial time is 0000 UTC 20 August), the modeled temperatures above $\sim 2-3 \mathrm{~km}$ are colder than the observed ones.

The top four frames of Fig. 13 show that, for the Fire run, daytime PBL depths at Hayman and Manitou, defined using the same 2-K threshold as the observations (L2013), are mostly within $300 \mathrm{~m}$ of the observed values from about 1700 to 2200 UTC (1000-1500 LST, the time of maximum surface heating in Fig. 11). Modeled L2013 depths tend to exceed observed values at other times. PBL depths from the Yonsei University scheme (YSU), which are based on a PBL Richardson-number criterion, are mostly consistent with those that are based on the 2-K threshold. Modeled daytime PBL depths at Manitou are mostly greater than that at Hayman until about 2000 UTC, and are similar thereafter, ${ }^{4}$ as is observed (Fig. 11). This is also true for the No Fire run (bottom two frames), even though PBL at Hayman is slightly deeper because of stronger surface buoyancy fluxes associated with the evergreen needleleaf ground cover (Fig. 11). Both PBL depths are more irregular on the afternoon of 22 August, probably because of the presence of more modeled clouds.

\section{c. The impact of adding horizontal diffusion and an additional grid layer}

In this section, we focus on the effects of WRF adjustments designed to improve the representation of nighttime

\footnotetext{
${ }^{4}$ Note that, since height is defined relative to profile location and Hayman is $\sim 30 \mathrm{~m}$ higher than Manitou, Hayman aboveground-level PBL depths will appear to be about $30 \mathrm{~m}$ shallower than Manitou PBL depths when they are at the same height above sea level; therefore, we focus only on differences greater than that.
} 


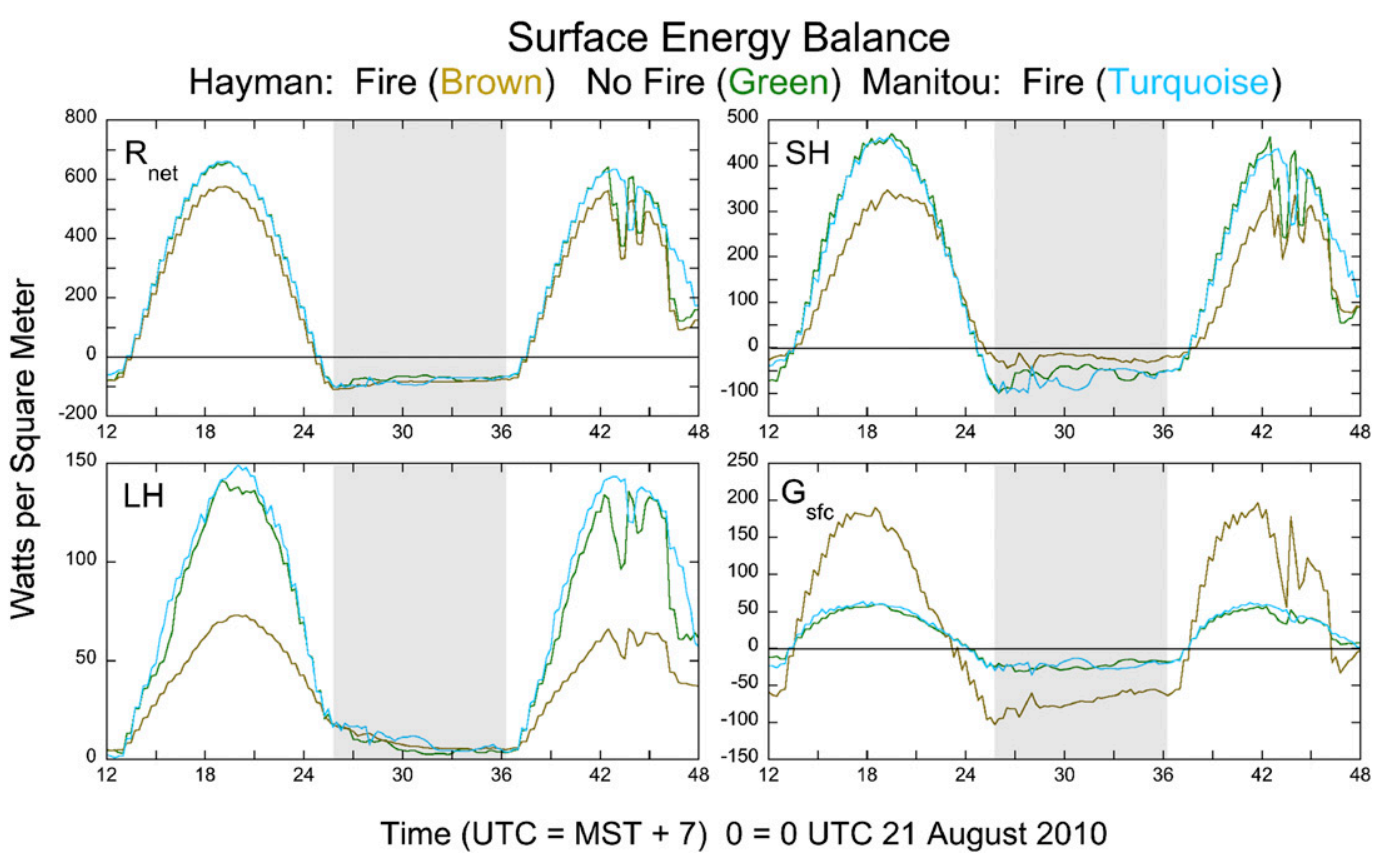

FIG. 11. Comparison of the Hayman surface energy budget from the Fire and No Fire runs with that of Manitou for the Fire run; $R_{\text {net }}=$ net radiation, $\mathrm{SH}=$ sensible heat flux; $\mathrm{LH}=$ latent heat flux, and $G_{\text {sfc }}=$ flux into the soil. Times from sunset to sunrise are shaded.

cold-air pooling. After showing the resulting changes in 1200 UTC T2M and T2M $\mathrm{M}_{\text {under }}$ in the Hayman-Manitou area, we examine time series of near-surface winds and temperatures at Manitou, MEFO, and Hayman. We then examine the vertical extent of the resulting modifications using the early-morning (1200 UTC) and early-afternoon (2000 UTC) temperature and wind profiles.

Maps of T2M and T2M under in Fig. 14 show that horizontal diffusion and an additional grid layer produce cooler air in the Trout Creek valley in which Manitou is located, especially for $\mathrm{T} 2 \mathrm{M}_{\text {under }}$. While there are slight changes with the introduction of horizontal diffusion, the biggest change is with the introduction of the new grid layer at $12.5 \mathrm{~m}$, with the darkest blues in the figure ( $\sim 280 \mathrm{~K})$ penetrating to Manitou and southward. Consistent with this, $\mathrm{T}_{2} \mathrm{M}_{\text {under }}$ at Manitou for the Fire run with both modifications (F+HD+10m-3.6.1; Fig. 15) was closest to (and sometimes cooler than) observations, reaching close to the observed $279 \mathrm{~K}$ at 1200 UTC 21 August and matching the minimum temperature of $281 \mathrm{~K}$ at 1000 UTC 21 August (hour 34 in Fig. 15), but $2-3 \mathrm{~h}$ too early. The effects of horizontal diffusion alone, although often small, cooled temperatures noticeably around 1000-1200 UTC 21 August (note also that $\mathrm{F}+\mathrm{HD}$ T2M $\mathrm{M}_{\text {under }}$ values for WRF v3.6 and v3.6.1 are almost identical). As in Fig. 10, T2M $\mathrm{M}_{\text {under }}$ in Fig. 15 tends to be too high during the day. T2M itself would follow the daytime observed 2-m temperature much as it does in Fig. 10, however, because the addition of horizontal diffusion and an additional grid layer has little effect (online supplemental Fig. S5).

The model wind directions at Manitou are close to observations for all runs that are shown. The model 2-m wind speeds in Fig. 15 are found by first replacing " 10 m" with " $2 \mathrm{~m}$ " in the output code to find the above-canopy and bare-ground wind speeds at heights closer to the measurement height and then performing a vegetationfraction-weighted average. The resulting values are only $25 \%-50 \%\left(1-2 \mathrm{~m} \mathrm{~s}^{-1}\right)$ higher than observations during the day. Nighttime overestimates reach $100 \%\left(1 \mathrm{~m} \mathrm{~s}^{-1}\right)$, but the $\mathrm{F}+\mathrm{HD}+10 \mathrm{~m}$ simulation dropped wind speeds enough to match observations closely approximately one-half of the time. For both day and night, part of the discrepancy could be traced to the effective height of the 2-m wind being at $5.8 \mathrm{~m}$ AGL. Use of a method analogous to Eqs. (1) and (2) to find undercanopy wind speed at $2 \mathrm{~m}$ leads to consistent underestimates, and therefore a more sophisticated method that incorporates canopy structure is needed. High near-surface wind speed biases are a well-known problem in WRF (e.g., Jimenez and Dudhia 2012, and references therein) that persists to this day (Barlage et al. 2016).

In Fig. 15, the observed winds at the two lowest levels of the MEFO tower tend to be more westerly (downslope) at night and much weaker through the period shown, relative to the observed winds at Manitou and the modeled winds at both locations (see the MEFO 


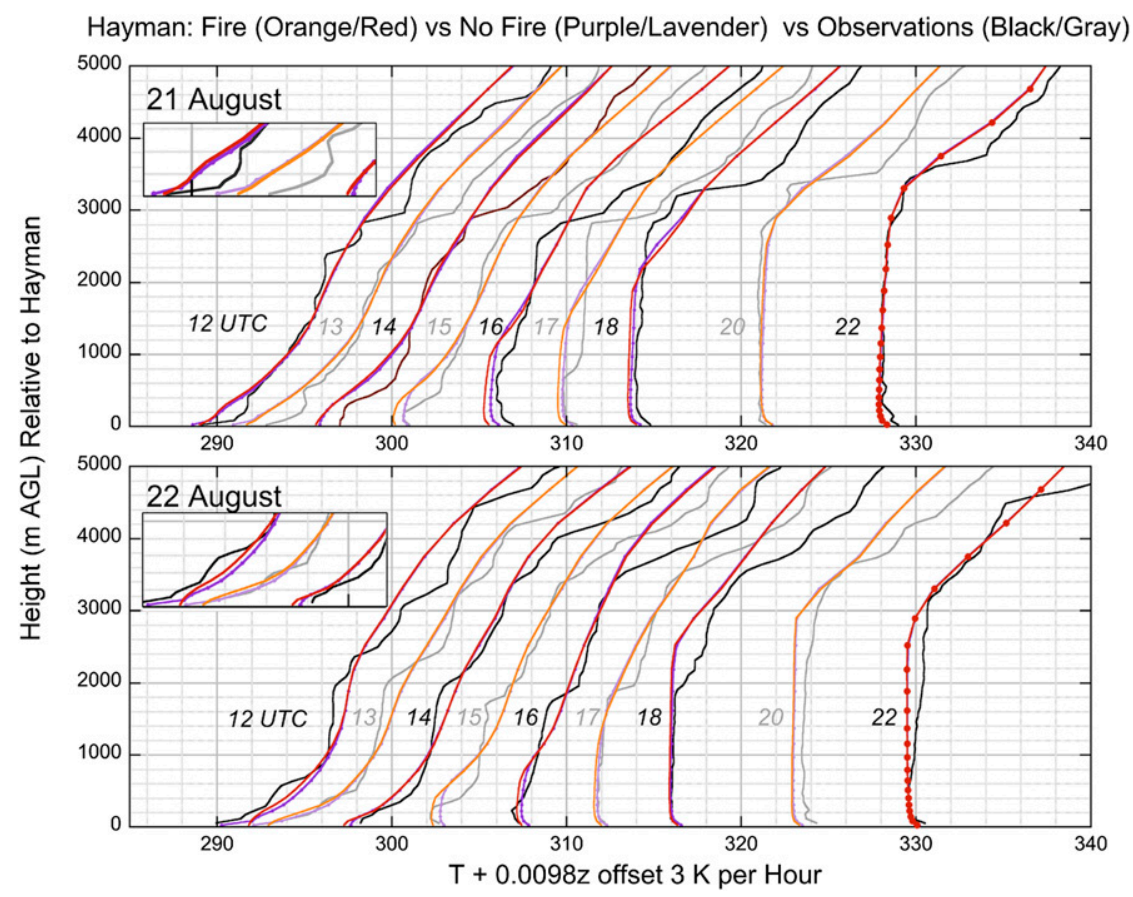

FIG. 12. Sequential soundings at Hayman for 21-22 Aug. Points on the 2200 UTC soundings for the Fire run are highlighted to show vertical grid points. Model profiles are instantaneous and vertical. Observed profiles follow the balloon location; they have been vertically smoothed and interpolated in time to the hour. The insets show the first three profiles, near the surface.

modeled results in online supplemental Fig. S6). Nevertheless, the $\mathrm{F}+\mathrm{HD}+10 \mathrm{~m}-3.6 .1$ simulation does capture some downslope flow: nighttime (0200-1215 UTC) vectoraveraged modeled wind directions at MEFO and Manitou are respectively $211^{\circ}$ and $168^{\circ}$ for 21 August and respectively $187^{\circ}$ and $167^{\circ}$ for 22 August, suggesting a downslope wind component for both locations (the local orientation of Trout Creek is north-south). Furthermore, the tower winds become more southerly with height (Fig. S7), although not as southerly as in the model. Vertical changes in wind direction through a canopy, also observed in Burns et al. (2011) at another mountain location under stable conditions, are not allowed in Noah-MP.

The weakness of the lowest-level winds at the MEFO tower relative to those at Manitou and in the model results likely is from the simulation not correctly capturing the difference between the vegetation at the two sites. Relative to Manitou, the MEFO tower is in a denser group of trees forming a deeper $(16 \mathrm{~m})$ canopy. In contrast, the simulations use the same 10-m canopy height at both locations, and the model vegetation fraction is actually smaller (0.5424) at the MEFO tower than at Manitou (0.5456). The wind speeds at the two highest tower levels (29.9 and $42.86 \mathrm{~m}$ ) in Fig. S7 are close to the modeled $10-\mathrm{m}$ wind speeds (effective height $13.8 \mathrm{~m}$ ). In a similar way, T2M (effective height $5.8 \mathrm{~m}$ ) appears to match temperatures at the three highest tower levels $(16.06-42.85 \mathrm{~m})$ better than at the two lowest levels (2.04 and $7.42 \mathrm{~m}$ ).

Model refinements do little to change surface conditions at Hayman, as can be seen from Fig. 16. Modeled wind direction and nighttime wind speeds are close to observations, but modeled daytime winds are $2-3 \mathrm{~m} \mathrm{~s}^{-1}$ stronger than the observed $2-4 \mathrm{~m} \mathrm{~s}^{-1}$ speeds.

How far do the near-surface horizontal differences extend upward? Figure 17 compares the 1200 UTC Hayman and Manitou observed and modeled altitude-adjusted temperature profiles. As expected from Figs. 15 and 16, the near-surface profile changes are more sensitive to model refinements at Manitou than at Hayman. The profiles for the $\mathrm{F}+\mathrm{HD}+10 \mathrm{~m}-3.6 .1$ run are generally closest to observations; therefore, they are compared with observations in the left panels. On 21 August, these profiles are consistent with observations above $400 \mathrm{~m}$ for Hayman and above $500 \mathrm{~m}$ for Manitou. Below those heights, modeled temperatures have a cool bias for Hayman and a warm bias for Manitou. Hayman remains warmer than Manitou to $\sim 300-400 \mathrm{~m}$ in the model, in contrast to $500 \mathrm{~m}$ for the observations. On 22 August, Hayman remains warmer than Manitou to $\sim 600 \mathrm{~m}$ for both model and observations, but modeled 

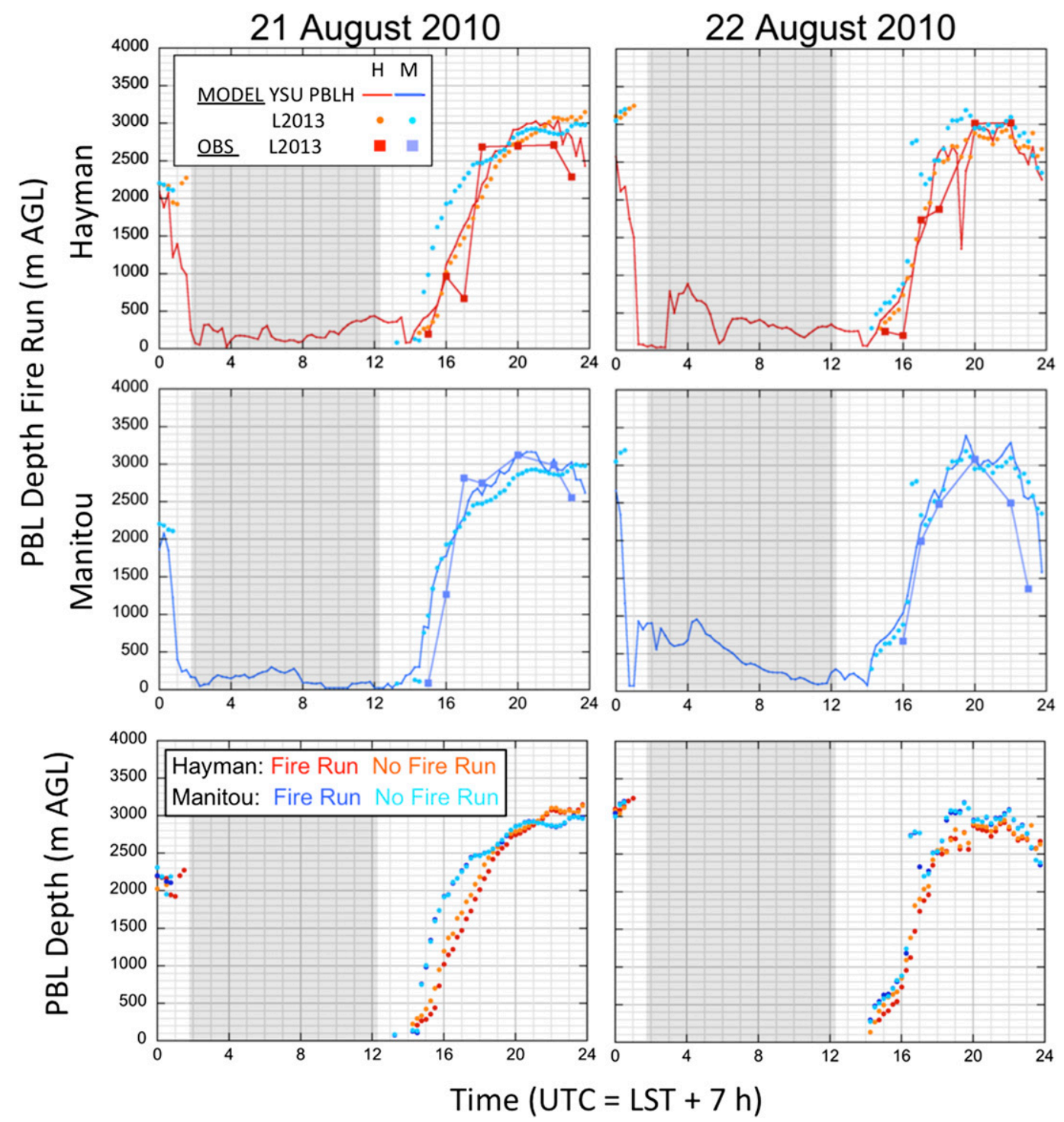

FIG. 13. PBL depths at (top) Hayman and (middle) Manitou, showing results from the Fire run in comparison with observations. YSU PBL depth is based on a PBL Richardson number criterion and is part of WRF/YSU output; L2013 PBL depth is based on LeMone et al. (2013). Modeled L2013 PBL depths for Manitou are superposed on Hayman for comparison purposes. (bottom) L2013 PBL depths at the two sites for the Fire run in comparison with the No Fire run. For all panels, times between sunset and sunrise are shaded and height above ground level is based on radiosonde-release elevation.

temperatures below $600 \mathrm{~m}$ are too warm for both. The too-warm temperatures nearer the surface at Manitou could be partially the result of timing: when the $\mathrm{F}+\mathrm{HD}+10 \mathrm{~m}-3.6 .1$ run produces the night's coolest 2-m temperatures at 1000 UTC 22 August (Fig. 15), the corresponding vertical profile shows temperatures that are much cooler than those at 1200 UTC from the surface to $\sim 150 \mathrm{~m}$ (Fig. 17). As noted earlier, the 1500 -m heightadjusted temperature at Hayman is about $0.3 \mathrm{~K}$ cooler than Manitou because the local height is used for the adjustment.
Note that Hayman is actually cooler than Manitou at $28 \mathrm{~m}$ for the No Fire run on 22 August. (This is easier to see in online supplemental Fig. S8). As seen in Fig. 10, this situation happened more than once at the surface. For the Fire run, the 28 - $\mathrm{m}$ Hayman temperatures are $\sim 1 \mathrm{~K}$ warmer than those at Manitou on both days. Differences are progressively closer to observations for the $\mathrm{F}+\mathrm{HD}$ and $\mathrm{F}+\mathrm{HD}+10 \mathrm{~m}-3.6 .1$ runs, with the temperature spread reaching a maximum at $28 \mathrm{~m}$ for the latter on 21 August and in the lower few hundred meters on 22 August. 


\section{UTC 21 August 2010}

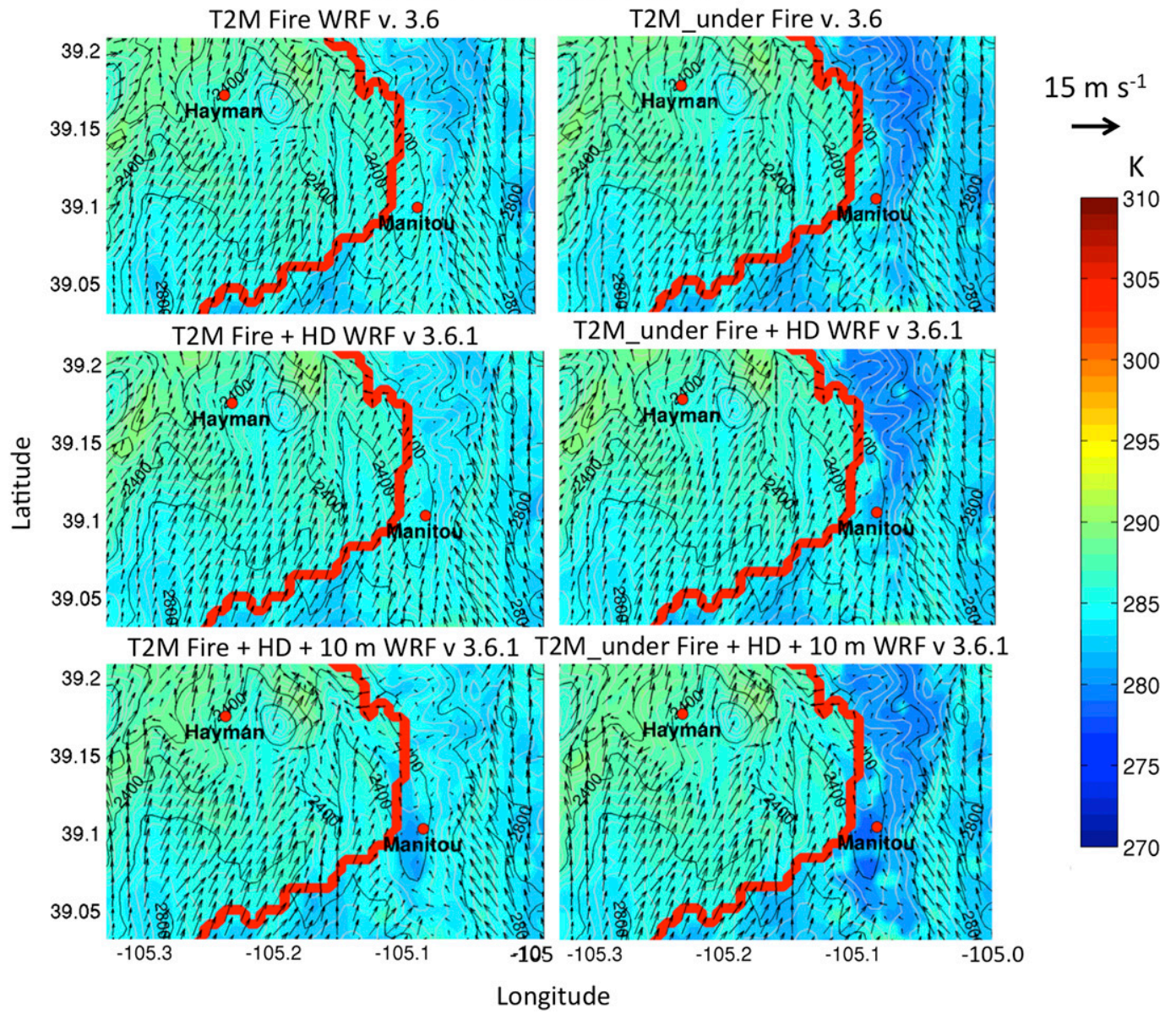

FIG. 14. Early-morning 21 Aug T2M, T2 $\mathrm{M}_{\text {under }}$, and diagnosed Noah-MP 10-m wind vectors for the Fire run (v3.6), the F+HD-3.6.1 run, and the F+HD+10m-3.6.1 run.

The 1200 UTC model and observed profiles of zonal and meridional wind components $U$ and $V$ in Fig. 18 differ somewhat for both 21 and 22 August, with slightly better agreement for $U$ than for $V$ on 22 August. Adding horizontal diffusion and an extra grid layer had only a minor effect except near the surface at Manitou, where the $\mathrm{F}+\mathrm{HD}+10 \mathrm{~m}-3.6 .1$ run brings the nearsurface wind closest to its observed value-but it is still too strong. The modeled winds corresponding to the F+HD+10m 1000 UTC temperature minimum on 22 August (Figs. 15 and 17) are appropriately weak near the surface, however.

Daytime profiles of height-adjusted temperature appear in Fig. 19. Because the profiles are deeper, and because we want to assess the similarity in temperature at the two sites through the PBL and above, altitudes above ground level and adjusted temperatures are calculated using the surface elevation at Manitou. All of the simulations produce similar temperature profiles that match observations through the PBL on 21 August, with temperatures above the PBL having a low bias, consistent with Fig. 12. Temperature spread among model runs and model differences from observations within the PBL increase on 22 August, especially at Hayman. Some of the spread is due to the presence of convectively induced secondary circulations (CISCs; Ching et al. 2014; Zhou et al. 2014), which are a common feature of fine-grid simulations (e.g., LeMone et al. 2010), including this one (online supplemental Fig. S9). Horizontal averaging makes the profiles from the F+HD - and F+HD+10m runs (Fig. 19 inset) nearly identical and clearly separates them from the Fire and No Fire runs, which are closer to observations. Horizontal standard deviations at this time are less than $\sim 0.2 \mathrm{~K}$ for all runs at Manitou and Hayman on 21 August, and, although they have similar values at Manitou on 22 August, horizontal standard deviations increase by up to $0.7 \mathrm{~K}$ for all runs including HD at Hayman. Given 

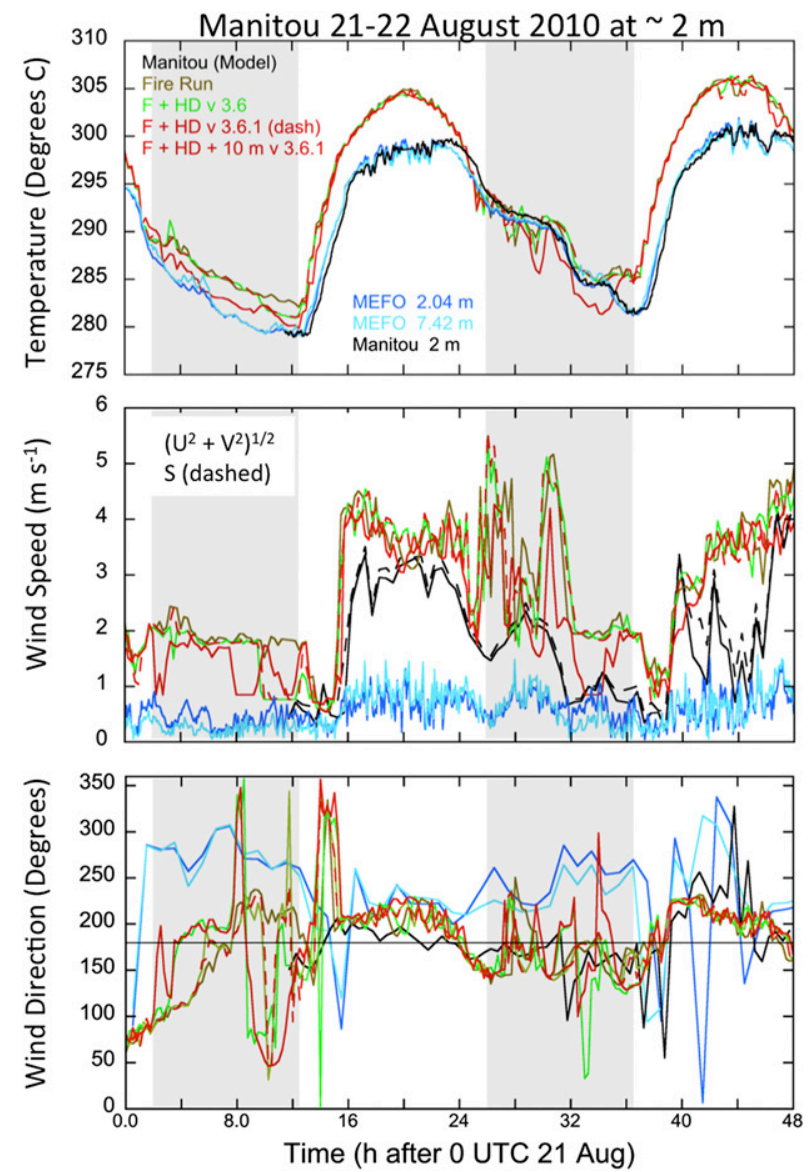

FIG. 15. Observations from Manitou and the 2.04- and 7.42-m levels on the MEFO micrometeorological tower (1.4 km to the west), in comparison with $\mathrm{T}_{2} \mathrm{M}_{\text {under }}$ and Noah-MP 2-m wind speed and direction from different model runs. The Noah-MP 2-m wind speed is found the same way as the $10-\mathrm{m}$ wind speed is but by using $2 \mathrm{~m}$ instead of $10 \mathrm{~m}$; wind direction at $2 \mathrm{~m}$ is assumed to be the same as at $10 \mathrm{~m}$. For observed wind speed, the solid and dashed black lines represent the vector average and the scalar average, respectively. A $180^{\circ}$ line is included for wind direction. Times from sunset to sunrise are shaded.

the $\sim 0.5-\mathrm{K}$ expected horizontal variability in temperature that is due to large eddies in the daytime PBL (e.g., Weckwerth et al. 1996), the model-observation temperature differences are surprisingly small.

The 2000 UTC wind profiles in Fig. 20 deviate even more from observations than those at 1200 UTC, especially on 22 August, with model-observation differences greatly exceeding differences between the model versions. As a result, horizontally averaged profiles were computed, but they did not differ much from the time-averaged profiles (not shown). As in the case of temperature, horizontal standard deviations for $U$ and $V$ at Hayman on 22 August for the HD run were larger by about the same factor when compared with 21 August and Manitou values. The lack of improvement is not
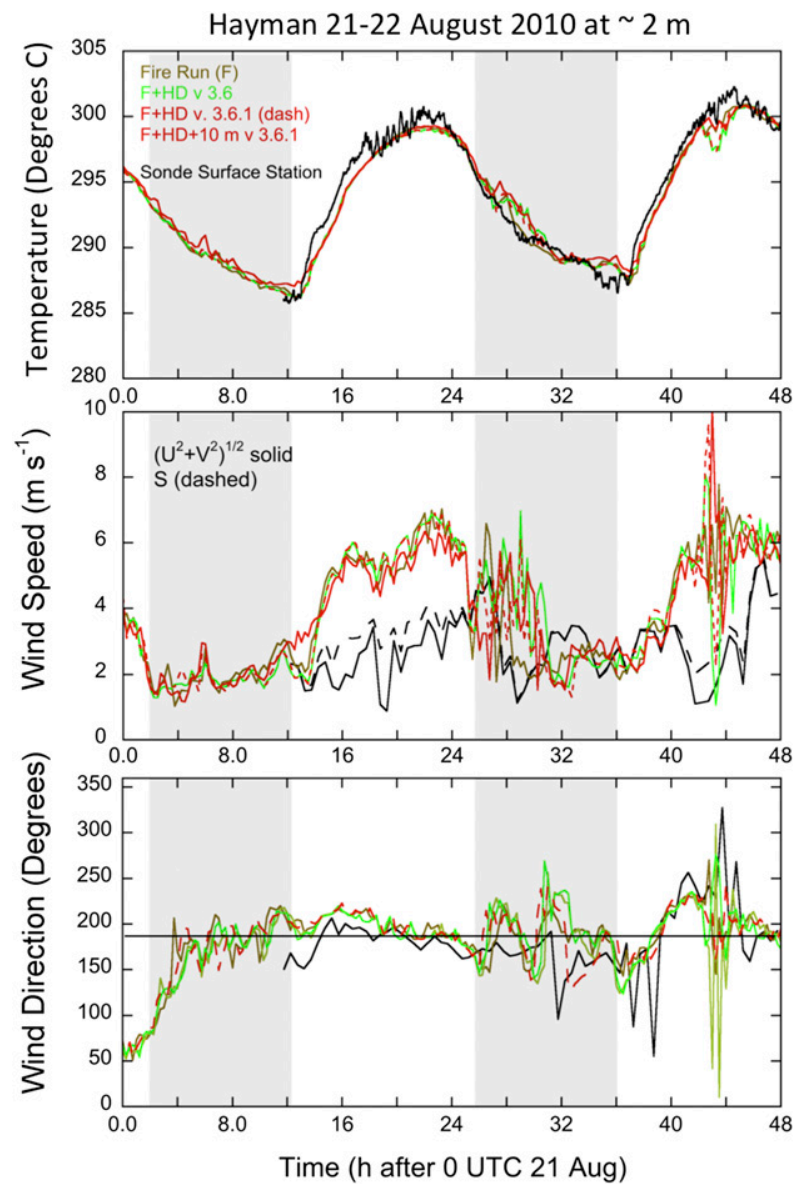

FIG. 16. As in Fig. 15, but for the Hayman site.

surprising: the model refinements were designed for stable boundary layers.

The differences between model and observed winds are more likely a result of model shortcomings than of sampling problems. The standard deviations, which are largest at the surface and largest for F+HD+10m-3.6.1, fall short of explaining the difference between observed and modeled winds, even in the presence of CISCs: Take a worst-case scenario, in which the radiosonde samples a horizontal-wind extremum for a sinusoidal CISC with standard deviation $\sigma$. If the model winds represent a CISC average, then the maximum difference between the instantaneous observation and the mean modeled wind would be $1.4 \sigma$, which even for the HD runs is far less than the difference between the modeled and observed winds at most heights. We also looked at the horizontally averaged model profiles corresponding to the balloon location when it was $\sim 250 \mathrm{~m}$ below PBL top for 22 August $(3.5 \mathrm{~km}$ to the northeast of Hayman and $0.53 \mathrm{~km}$ north-northeast of Manitou), and found them-not surprisingly - to be very similar to those centered on the sounding origins. 

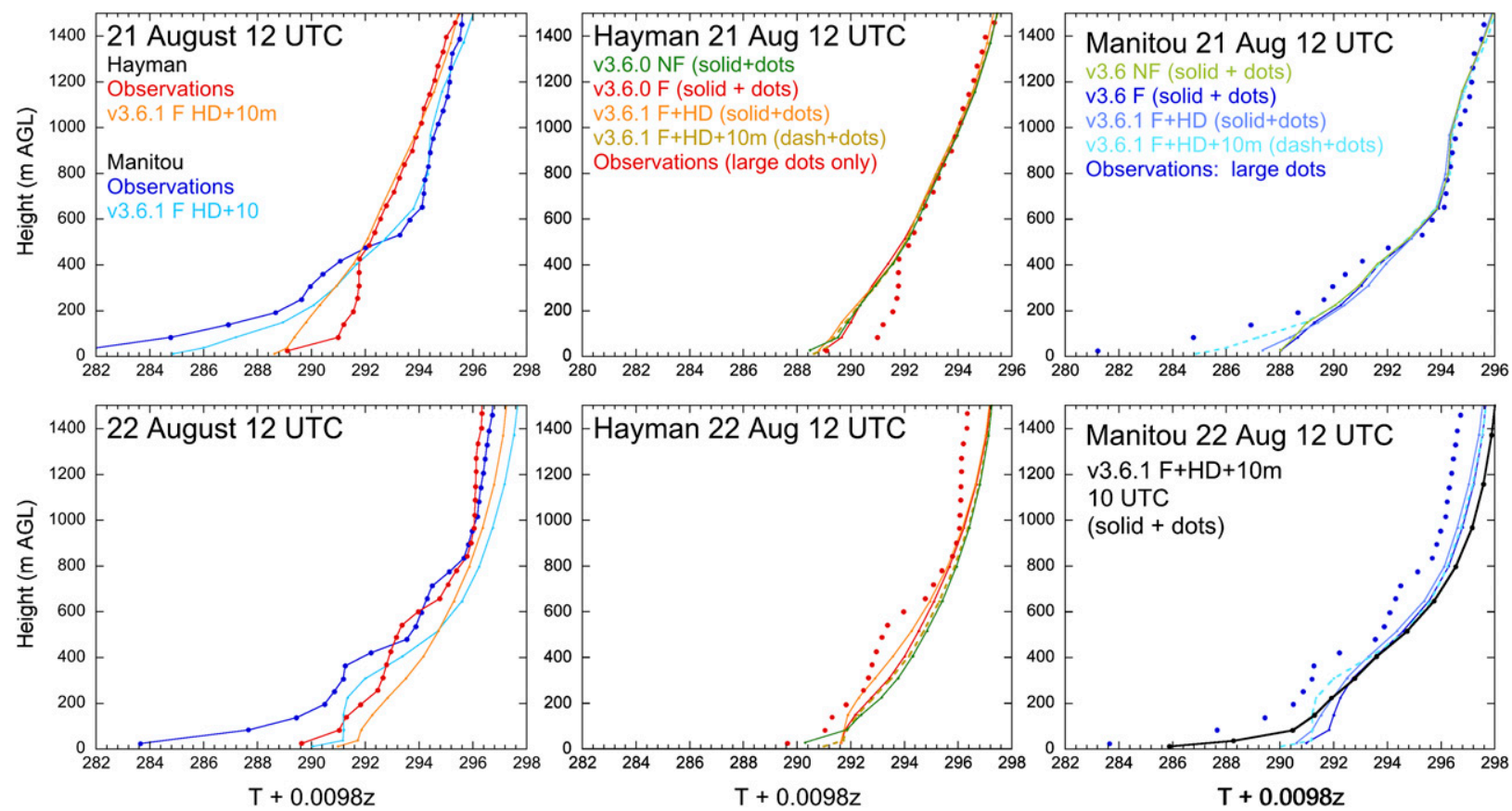

FIG. 17. Presunrise profiles of altitude-adjusted temperature. For the model, hour averages, centered at 1200 UTC over Manitou and Hayman, are shown. Also included is the hour-averaged 1000 UTC model profile corresponding to minimum 2-m temperature for F+HD+10m-3.6.1 on 22 August at Manitou (Fig. 15). For the observations, vertically smoothed soundings interpolated to 1200 UTC are shown. Manitou heights above ground level are relative to Manitou, and Hayman heights above ground level are relative to Hayman.

\section{Conclusions}

Comparisons of observed surface temperatures and temperature profiles at a grassy site that was severely burned 8 years earlier (Hayman) with an unaffected forested site $15 \mathrm{~km}$ to the southeast (Manitou) reveal much warmer nighttime temperatures at Hayman. Daytime temperatures and afternoon boundary layer depths were nearly the same at the two sites. Nighttime temperature differences extended from an average height of $500 \mathrm{~m}$ AGL to the surface, where Hayman temperatures are up to $7 \mathrm{~K}$ warmer than those at Manitou. Weak winds and the higher terrain that separates the two sites allow these differences to develop.

A series of fine-grid WRF simulations coupled to the Noah-MP land surface model suggests that fire-induced surface changes account for approximately one-half of the difference in nighttime $2-\mathrm{m}$ temperatures between the two sites, with cold pooling at Manitou accounting for the other half. The fire scar (including Hayman) was represented in the Fire run by grassland with no organic material in the soil; the surface in and around the fire scar was represented in the No Fire run by prefire vegetation (mostly evergreen needleleaf). If the vegetation was evergreen needleleaf, a $10-\mathrm{cm}$ organic layer replaced the top soil layer in Noah-MP. These fireinduced changes raised the modeled surface air temperature at Hayman by $3-5 \mathrm{~K}$, to values close to what was observed. Examination of the surface energy budget reveals that the relative nighttime warmth is due to the release of stored heat from the uninsulated (organic free) soil, which has a much larger effect than the weaker downward heat fluxes associated with the change from trees to grass. In general, the modeled changes in the surface energy budget are consistent with changes resulting from vegetation and soil changes in 3-15-yr-old fire scars observed at several locations. The Manitou and Hayman nighttime temperatures were about the same for the No Fire run.

Introduction of an extra grid layer and horizontal diffusion (as opposed to terrain-following diffusion) (run F+HD $+10 \mathrm{~m}$ ) to the Fire run was necessary to fully represent the other half of the nighttime 2-m temperature difference between Hayman and Manitou, which was associated with the lowering of temperatures by cold-air pooling in the Trout Creek valley, where the Manitou and MEFO sites were located. The same changes did not significantly affect nighttime 2-m temperatures at Hayman, which was on a slope. The vertical extent of the temperature differences at 1200 UTC in the fully modified simulation is within $\sim 100 \mathrm{~m}$ of 
12 UTC 21 August 2010
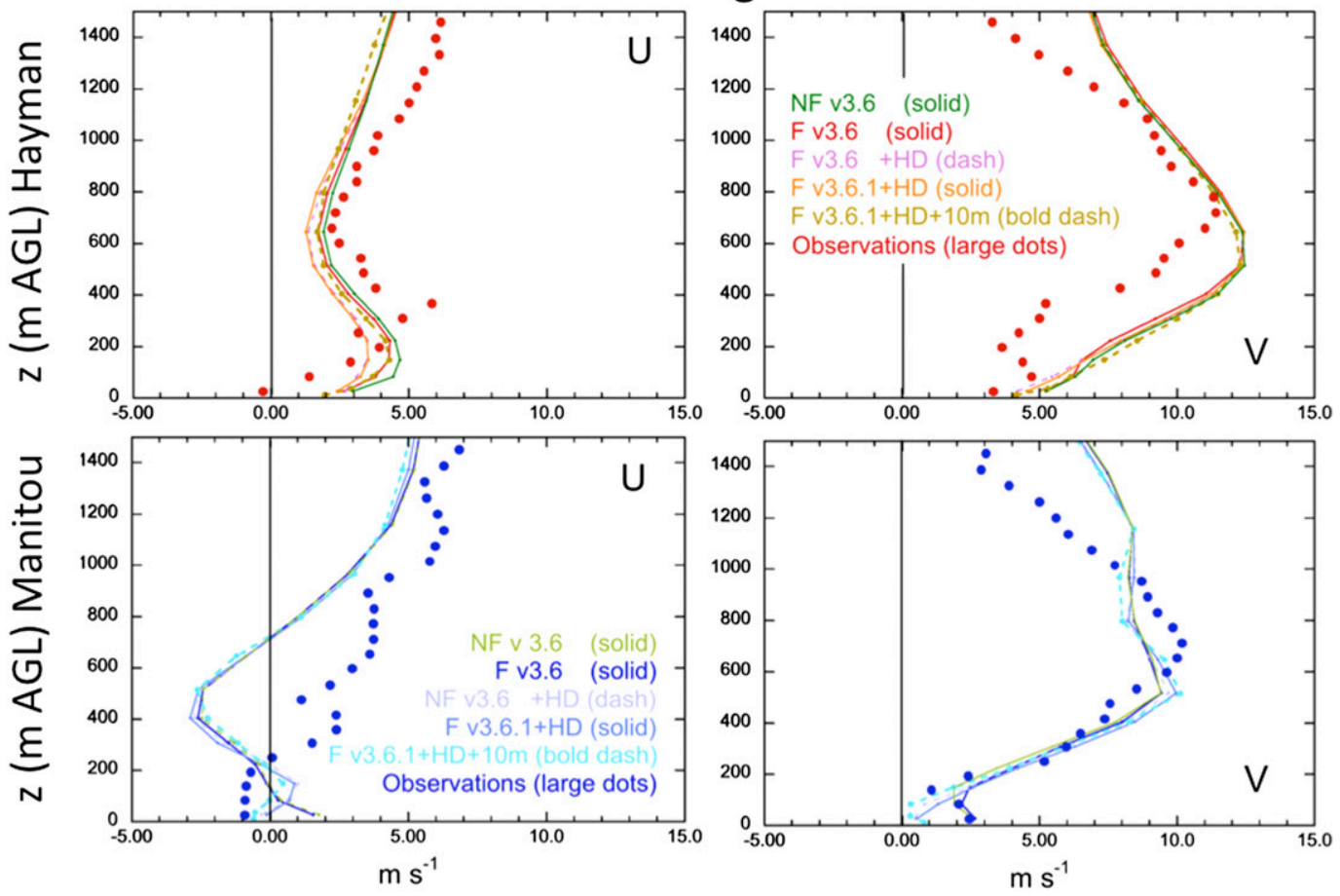

12 UTC 22 August 2010
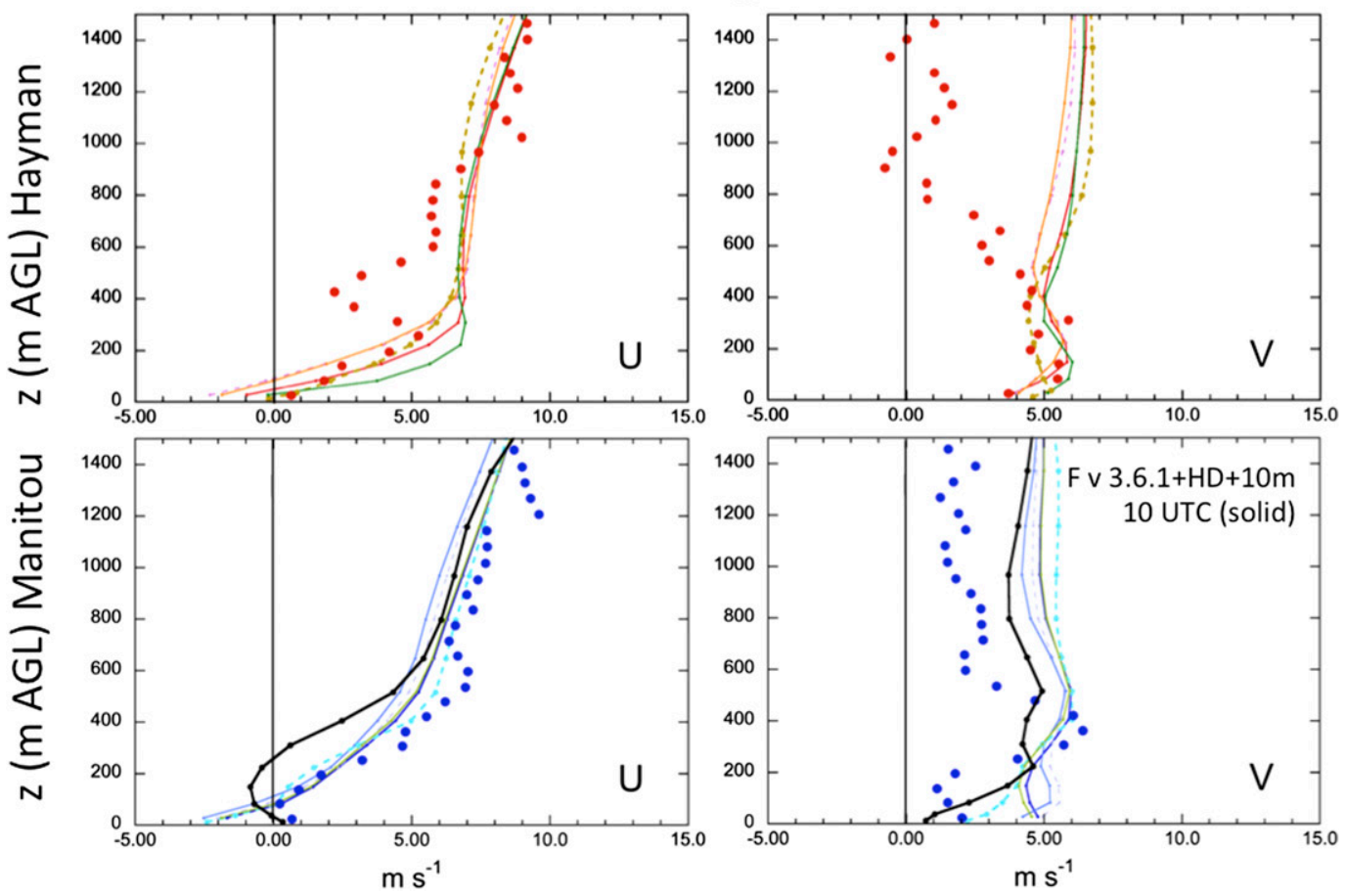

FIG. 18. As in Fig. 17, but for zonal and meridional wind components $U$ and $V$. 

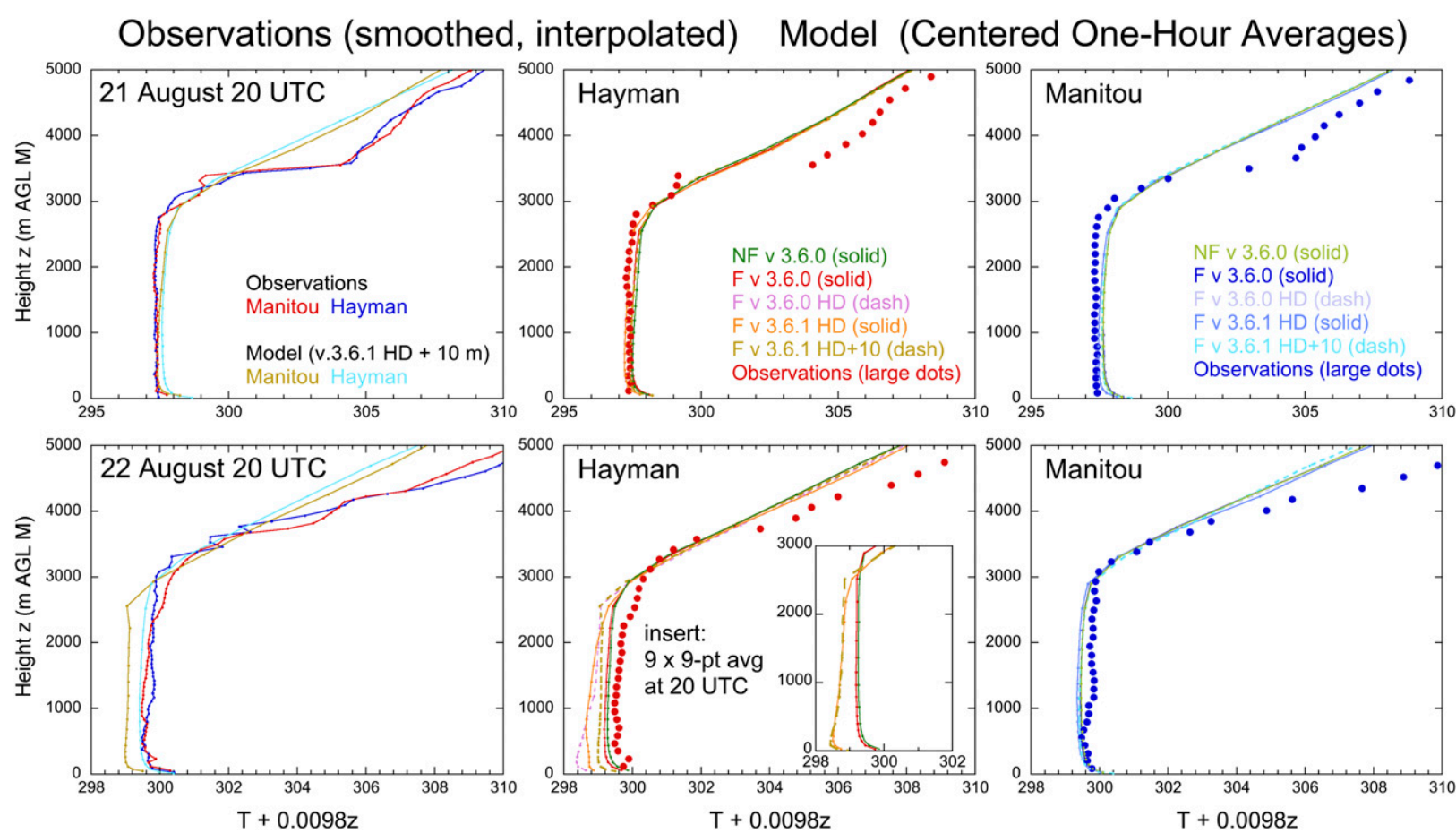

FIG. 19. As in Fig. 17, but for 2000 UTC (1300 LST) and use of Manitou model and actual elevations for height above ground level and computation of height-adjusted temperature for both sites. The insert includes $9 \times 9$ point $(4.5 \mathrm{~km} \times 4.5 \mathrm{~km})$ average profiles centered at Hayman at 2000 UTC, referenced to average surface elevation centered at Hayman.

observations, but the magnitude of the differences was too small. Given that the coolest modeled and observed near-surface temperatures at Manitou occurred at different times, this discrepancy could in part be a matter of timing.

At the surface, the southerly wind direction at Manitou and Hayman and the nighttime wind speed at Hayman were well replicated for all runs. The $\mathrm{F}+\mathrm{HD}+10 \mathrm{~m}-3.6 .1$ run did the best job of simulating the observed nighttime Manitou wind speeds, matching them about one-half of the time. The modeled nighttime winds at the MEFO micrometerological tower only $1.4 \mathrm{~km}$ west of Manitou were more southerly than the observed downslope winds, however, especially at the lowest levels. Also, the observed near-surface winds at the tower were weaker than both those modeled and those at Manitou though the diurnal cycle, a likely result of the taller and denser trees. During the day, the modeled surface winds at all sites tended to be too high. Winds in the lowest $1500 \mathrm{~m}$ were not as well reproduced in the model.

The Fire simulation represented the similarity in the daytime temperature profiles reasonably well. As observed, the modeled PBL tended to grow faster, with greater depths at Manitou than at Hayman until $\sim 2000$ UTC, after which the two depths were similar.
This evolution likely reflects larger surface buoyancy fluxes at Manitou gradually being offset by horizontal mixing and ingestion of air that was unaffected by the fire scar into the growing PBL at the two sites. Simulation refinements had little effect on daytime temperature profiles at 2000 UTC 21 August but appeared to degrade the Hayman profiles on 22 August. There were considerable differences between modeled and observed 2000 UTC wind profiles, even allowing for the effects of partially resolved PBL convection, especially on 22 August.

Although the simulations did a reasonable job of separating out the roles of local surface modification and mesoscale terrain-induced flow in determining the differences between Hayman and Manitou, there is room for improvement. More realistic prefire conditions would have been desirable. The choice of $10 \mathrm{~cm}$ for the thickness of the organic layer was dictated by the thickness of the top soil layer in Noah-MP: the organic layer was not necessarily either that thick or that solid. Also, although we modified the near-surface model winds and temperatures to better correspond to the heights of our observations, continued development of more compatible surface diagnostics and observation strategies is needed for better model-observation comparisons. 
Centered $9 \times 9$ Grid-Point Average Wind $(4.5 \mathrm{~km} \times 4.5 \mathrm{~km})$ 20 UTC 21 August 2010

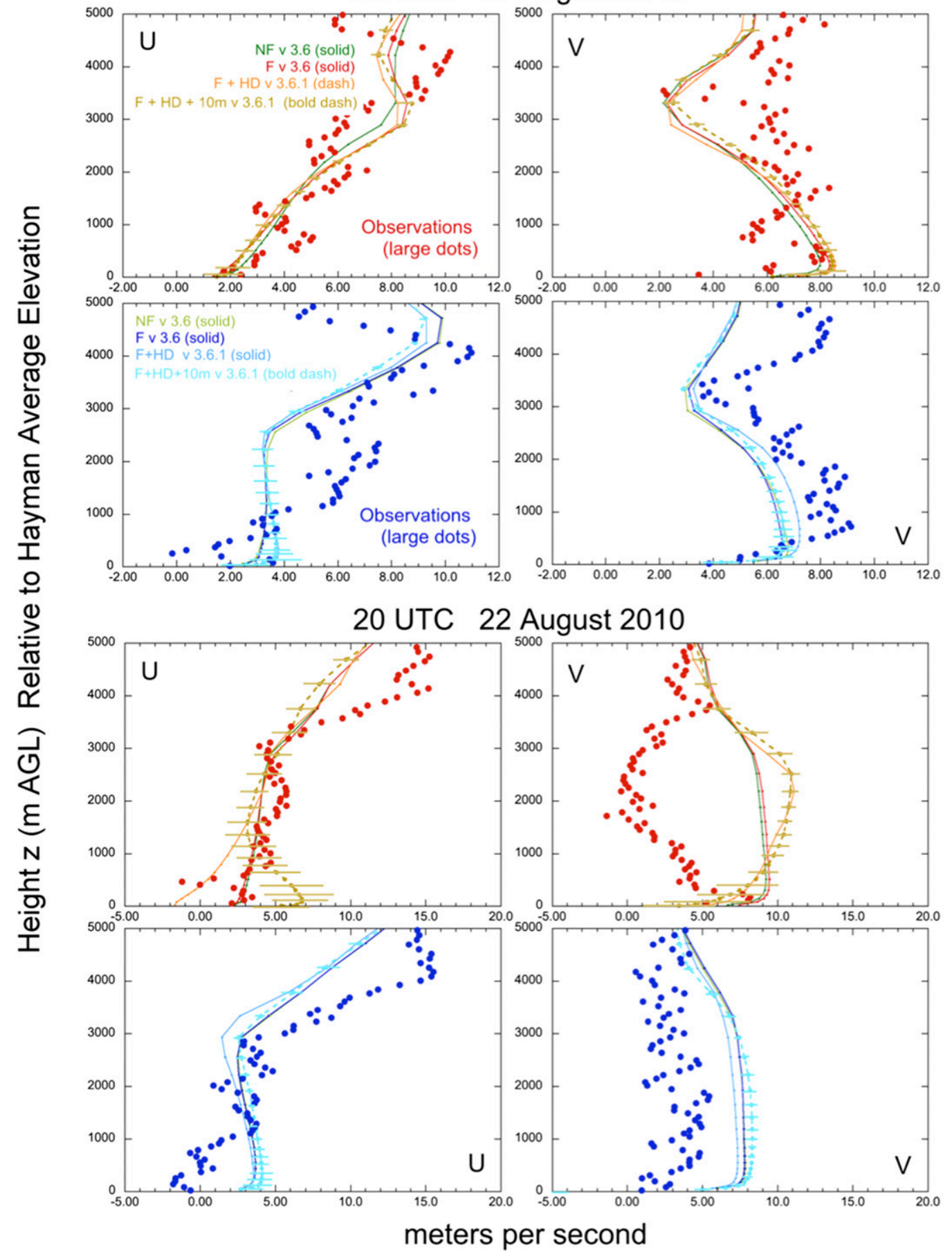

FIG. 20. As in Fig. 18, but the wind components $U$ and $V$ at 2000 UTC are averaged horizontally over 81 grid points $(4.5 \mathrm{~km} \times 4.5 \mathrm{~km})$. The largest horizontal standard deviations, for $\mathrm{F}+\mathrm{HD}+10 \mathrm{~m}-3.6 .1$, are shown. Local averaged elevations are used to calculate height above ground level. 
Acknowledgments. The measurements were taken as a part of the BEACHON project, which was funded through the National Center for Atmospheric Research (NCAR) BEACHON and Water System Programs. Along with the BEACHON and Water System Programs, the USDA National Institute for Food and Agriculture Agricultural and Food Research Initiative provided funding for this work (Awards 2015-6700323508 and 2015-67003-23460). NCAR's Environmental Observations Laboratory (EOL), along with two of the authors (Chen and Barlage) and three students (Derek Starkenberg from University of Colorado and Brian Bitterworth and George Zachos from University of North Carolina) launched radiosondes. EOL processed and validated the data. MEFO micrometeorological tower data were provided by Edward Patton of NCAR. Holger Vomel of EOL helped resolve inconsistencies in elevations from various sources. Kevin Sampson of NCAR prepared the map in Fig. 1. Thanks are given to the two anonymous reviewers whose comments greatly improved the paper.

\section{REFERENCES}

Alkama, R., and A. Cescatti, 2016: Biophysical climate impacts of recent changes in global forest cover. Science, 351, 600-604, doi:10.1126/science.aac8083.

Amiro, B. D., and Coauthors, 2006: The effect of post-fire stand age on the boreal forest energy balance. Agric. For. Meteor., 140, 41-50, doi:10.1016/j.agrformet.2006.02.014.

Barlage, M., M. Tewari, F. Chen, G. Miguez-Macho, Z.-L. Yang, and G.-Y. Niu, 2015: The effect of groundwater interaction in North American regional climate simulations with WRF/Noah-MP. Climatic Change, 129, 485-498, doi:10.1007/s10584-014-1308-8.

_- S. Miao, and F. Chen, 2016: Impact of physics parameterizations on high-resolution weather prediction over two Chinese megacities. J. Geophys. Res., 121, 4487-4498, doi:10.1002/2015JD024450.

Belcher, S. E., I. N. Harman, and J. J. Finnigan, 2012: The wind in the willows: Flows in forest canopies in complex terrain. Annu. Rev. Fluid Mech., 44, 479-504, doi:10.1146/annurev-fluid-120710-101036.

Billings, B. J., V. Grubišić, and R. D. Borys, 2006: Maintenance of a mountain valley cold pool: A numerical study. Mon. Wea. Rev., 134, 2266-2278, doi:10.1175/MWR3180.1.

Burns, S. P., and Coauthors, 2011: Atmospheric stability effects on wind fields and scalar mixing within and just above a subalpine forest in sloping terrain. Bound.-Layer Meteor., 138, 231-262, doi:10.1007/s10546-010-9560-6.

Chambers, S. D., and F. S. Chapin III, 2002: Fire effects on surfaceatmosphere energy exchange in Alaskan black spruce ecosystems: Implications for feedbacks to regional climate. J. Geophys. Res., 107, 8145, doi:10.1029/2001JD000530.

_- J. Beringer, J. T. Randerson, and F. S. Chapin III, 2005: Fire effects on net radiation and energy partitioning: Contrasting responses of tundra and boreal forest ecosystems. J. Geophys. Res., 110, D09106, doi:10.1029/2004JD005299.

Chen, F., and Y. Zhang, 2009: On the coupling strength between the land surface and the atmosphere: From viewpoint of surface exchange coefficients. Geophys. Res. Lett., 36, L10404, doi:10.1029/ 2009GL037980.
Ching, J., R. Rotunno, M. LeMone, A. Martilli, B. Kosovic, P. A. Jimenez, and J. Dudhia, 2014: Convectively induced secondary circulations in fine-grid mesoscale numerical weather prediction models. Mon. Wea. Rev., 142, 3284-3302, doi:10.1175/ MWR-D-13-00318.1.

Cornford, C. E., 1938: Katabatic winds and the prevention of frost damage. Quart. J. Roy. Meteor. Soc., 64, 553-592, doi:10.1002/ qj. 49706427702 .

Dore, S., M. Montes-Helu, S. C. Hart, B. A. Hungate, G. W. Koch, J. B. Moon, A. J. Finkral, and T. E. Kolb, 2012: Recovery of ponderosa pine ecosystem carbon and water fluxes from thinning and stand-replacing fire. Global Change Biol., 18, 3171-3185, doi:10.1111/j.1365-2486.2012.02775.x.

Dudhia, J., 1989: Numerical study of convection observed during the Winter Monsoon Experiment using a mesoscale twodimensional model. J. Atmos. Sci., 46, 3077-3107, doi:10.1175/ 1520-0469(1989)046<3077:NSOCOD>2.0.CO;2.

Euskirchen, E. S., A. D. McGuire, T. S. Rupp, F. S. Chapin III, and J. E. Walsh, 2009: Projected changes in atmospheric heating due to changes in fire disturbance and the snow season in the western Arctic, 2003-2100. J. Geophys. Res., 114, G04022, doi:10.1029/2009JG001095.

Finney, M. A., and Coauthors, 2003: Fire behavior, fuel treatments, and fire suppression on the Hayman fire. In Hayman fire case study, USDA Forest Service Rocky Mountain Research Station General Tech. Rep. RMRS-GTR-114, 33-180. [Available online at http://www.fs.fed.us/rm/pubs/ rmrs_gtr114.pdf.]

Hong, S.-Y., J. Dudhia, and S.-H. Chen, 2004: A revised approach to ice microphysical processes for the bulk parameterization of clouds and precipitation. Mon. Wea. Rev., 132, 103-120, doi:10.1175/1520-0493(2004)132<0103:ARATIM>2.0.CO;2.

—, Y. Noh, and J. Dudhia, 2006: A new vertical diffusion package with an explicit treatment of entrainment processes. Mon. Wea. Rev., 134, 2318-2341, doi:10.1175/MWR3199.1.

Horst, T. W., S. R. Semmer, and G. Maclean, 2015: Correction of a non-orthogonal, three-component sonic anemometer for flow distortion by transducer shadowing. Bound.-Layer Meteor., 155, 371-395, doi:10.1007/s10546-015-0010-3.

Jiménez, P. A., and J. Dudhia, 2012: Improving the representation of resolved and unresolved topographic effects on surface wind in the WRF Model. J. Appl. Meteor. Climatol., 51, 300316, doi:10.1175/JAMC-D-11-084.1.

Jin, Y., J. T. Randerson, S. J. Goetz, P. S. A. Beck, M. M. Loranty, and M. L. Goulden, 2012: The influence of burn severity on postfire vegetation recovery and albedo change during early succession in North American boreal forests. J. Geophys. Res., 117, G01036, doi:10.1029/2011JG001886.

Kain, J. S., 2004: The Kain-Fritsch parameterization scheme: An update. J. Appl. Meteor., 43, 170-181, doi:10.1175/ 1520-0450(2004)043<0170:TKCPAU>2.0.CO;2.

Lawrence, D. M., and A. G. Slater, 2008: Incorporating organic soil into a global climate model. Climate Dyn., 30, 145-160, doi:10.1007/s00382-007-0278-1.

LeMone, M. A., K. Ikeda, R. L. Grossman, and M. W. Rotach, 2003: Horizontal variability of 2-m temperature at night during CASES-97. J. Atmos. Sci., 60, 2431-2449, doi:10.1175/ 1520-0469(2003)060<2431:HVOMTA > 2.0.CO;2.

—, F. Chen, M. Tewari, J. Dudhia, B. Geerts, Q. Miao, R. L. Coulter, and R. L. Grossman, 2010: Simulating the IHOP_2002 fair-weather CBL with the WRF-ARW-Noah modeling system. Part II: Structures from a few kilometers to $100 \mathrm{~km}$ across. Mon. Wea. Rev., 138, 745-764, doi:10.1175/2009MWR3004.1. 
—, M. Tewari, F. Chen, and J. Dudhia, 2013: Objectively determined fair-weather CBL depths in the ARW-WRF Model and their comparison to CASES-97 observations. Mon. Wea. Rev., 141, 30-54, doi:10.1175/MWR-D-12-00106.1.

Liu, H., and J. T. Randerson, 2008: Interannual variability of surface energy exchange depends on stand age in a boreal forest fire chronosequence. J. Geophys. Res., 113, G01006, doi:10.1029/2007JG000483.

,-- J. Lindfors, and F. S. Chapin III, 2005: Changes in the surface energy budget after fire in boreal ecosystems of interior Alaska: An annual perspective. J. Geophys. Res., 110, D13101, doi:10.1029/2004JD005158.

Mesinger, F., and Coauthors, 2006: North American Regional Reanalysis. Bull. Amer. Meteor. Soc., 87, 343-360, doi:10.1175/ BAMS-87-3-343.

Mlawer, E. J., S. J. Taubman, P. D. Brown, J. J. Iacono, and S. A. Clough, 1997: Radiative transfer for inhomogeneous atmospheres: RRTM, a validated correlated- $k$ model for the longwave. J. Geophys. Res., 102, 16 663-16 682, doi:10.1029/97JD00237.

Moody, J. A., and P. Nyman, 2013: Variations in soil detachment rates after wildfire as a function of soil depth, flow properties and root properties. U.S. Geological Survey Scientific Investigations Rep. 2012-5233, 40 pp. [Available online at http:// pubs.usgs.gov/sir/2012/5233/SIR12-5233-508.pdf.]

Moore, R., 1992: Soil survey of Pike National Forest, eastern part Colorado, parts of Douglas, El Paso, Jefferson, and Teller counties. National Cooperative Soil Survey Publ., 106 pp. [Available online at http://www.nrcs.usda.gov/Internet/FSE_ MANUSCRIPTS/colorado/pikeNF_CO1992/pike.pdf.]

NCAR Earth Observing Laboratory, 2010a: BEACHON QC radiosonde data-Hayman site, version 1.0. UCAR/NCAR Earth Observing Laboratory, accessed 2 November 2010, doi:10.5065/D6D50K5N.

_ 2010b: BEACHON QC radiosonde data-Manitou site, version 1.0. UCAR/NCAR Earth Observing Laboratory, accessed 2 November 2010, doi:10.5065/D68C9TFC.

- 2010c: ISS WXT surface meteorology data. UCAR/NCAR Earth Observing Laboratory, accessed 2 November 2010. [Available online at http://data.eol.ucar.edu/dataset/496.004.] , 2010d: Preliminary Manitou Experimental Forest Observatory micrometeorological tower instantaneous winds and temperatures. UCAR/NCAR Earth Observing Laboratory, accessed 27 May 2015. [Available from the author or online at https://wiki.ucar.edu/display/mfo/Manitou+Experimental+ Forest+Observatory; please contact Edward Patton at NCAR before downloading or using these data.]

NCEP Climate Prediction Center and UCAR Joint Office for Science Support, 2000: NCEP/CPC Four-Kilometer Precipitation Set, Gauge, and Radar (updated quarterly). NCAR Computational and Information Systems Laboratory Research Data Archive, accessed summer 2013 for precipitation, summer 2014 for Noah-MP offline runs, and 2 March 2015 for WRF runs. [Available online at http://rda.ucar.edu/datasets/ds507.5/.]

Niu, G.-Y., and Z.-L. Yang, 2004: Effects of vegetation canopy processes on snow surface energy and mass balances. J. Geophys. Res., 109, D23111, doi:10.1029/2004JD004884.

— , and Coauthors, 2011: The community Noah land surface model with multiparameterization options (Noah-MP): 1. Model description and evaluation with local-scale measurements J. Geophys. Res., 116, D12109, doi:10.1029/2010JD015139.

NOAA/NCEP, 2000: NCEP FNL Operational Model Global Tropospheric Analyses, continuing from July 1999 (updated daily). NCAR Computational and Information Systems Lab- oratory Research Data Archieve, accessed 3 April 2015, doi:10.5065/D6M043C6.

Oke, T. R., 1987: Boundary Layer Climates. 2nd ed. Methuen, 435 pp.

Ortega, J., and Coauthors, 2014: Overview of the Manitou Experimental Forest Observatory: Site description and selected science results from 2008 to 2013. Atmos. Chem. Phys., 14, 6345-6367, doi:10.5194/acp-14-6345-2014.

Randerson, J. T., and Coauthors, 2006: The impact of boreal forest fire on climate warming. Science, 314, 1130-1132, doi:10.1126/ science. 1132075.

Reen, B. P., D. R. Stauffer, K. J. Davis, and A. R. Desai, 2006: A case study on the effects of heterogeneous soil moisture on mesoscale boundary-layer structure in the southern Great Plains, U.S.A. Part II: Mesoscale modelling. Bound.-Layer Meteor., 120, 275-314, doi:10.1007/s10546-006-9056-6.

Roccaforte, J. P., P. Z. Fulé, W. W. Chancellor, and D. C. Laughlin, 2012: Woody debris and tree regeneration dynamics following severe wildfires in Arizona ponderosa pine forests. Can. J. For. Res., 42, 593-604, doi:10.1139/x2012-010.

Romme, W. H., T. T. Veblen, M. R. Kaufmann, R. Sherriff, and C. M. Regan, 2003: Ecological effects of the Hayman fire. In Hayman fire case study, USDA Forest Service Rocky Mountain Research Station General Tech. Rep. RMRS-GTR-114, 181-262. [Available online at http://www.fs.fed.us/rm/pubs/ rmrs_gtr114.pdf.]

Savage, M., and J. N. Mast, 2005: How resilient are southwestern ponderosa pine forests after crown fires? Can. J. For. Res., 35, 967-977, doi:10.1139/x05-028.

Strom, B. A., and P. Z. Fulé, 2007: Pre-wildfire fuel treatments affect long-term ponderosa pine forest dynamics. Int. J. Wildland Fire, 16, 128-138, doi:10.1071/WF06051.

Viereck, L. A., 1982: Effects of fire and firelines on active layer thickness and soil temperatures in interior Alaska. Proc. Fourth Canadian Permafrost Conf., Calgary, AB, Canada, Canadian Geotechnical Society, 123-135. [Available online at http://pubs.aina.ucalgary.ca/cpc/CPC4-123.pdf.]

Weckwerth, T. M., J. W. Wilson, and R. M. Wakimoto, 1996: Thermodynamic variability within the convective boundary layer due to horizontal convective rolls. Mon. Wea. Rev., 124, 769-784, doi:10.1175/1520-0493(1996)124<0769:TVWTCB >2.0.CO;2.

Whiteman, C. D., 2000: Mountain Meteorology: Fundamentals and Applications. Oxford University Press, $355 \mathrm{pp}$.

Yang, Z.-L., X. Cai, G. Zhang, A. A. Tavakoly, Q. Jin, L. H. Meyer, and X. Guan, 2011a: The community Noah land surface model with multi-parameterization options (Noah-MP): Technical description. University of Texas at Austin Center for Integrated Earth System Science Tech. Rep., 72 pp. [Available online at: http://www.jsg. utexas.edu/noah-mp/files/noah-mp_technote_v0.2.pdf.]

, and Coauthors, 2011b: The community Noah land surface model with multiparameterization options (Noah-MP): 2. Evaluation over global river basins. J. Geophys. Res., 116, D12110, doi:10.1029/2010JD015140.

Zängl, G., 2002: An improved method for computing horizontal diffusion in a sigma-coordinate model and its application to simulations over mountainous topography. Mon. Wea. Rev., 130, 1423-1432, doi:10.1175/1520-0493(2002)130<1423: AIMFCH $>2.0 . \mathrm{CO} ; 2$.

, 2005: Formation of extreme cold-air pools in elevated sinkholes: An idealized numerical process study. Mon. Wea. Rev., 133, 925-941, doi:10.1175/MWR2895.1.

Zhou, B., J. S. Simon, and F. K. Chow, 2014: The convective boundary layer in the terra incognita. J. Atmos. Sci., 71, 2545-2563, doi:10.1175/JAS-D-13-0356.1. 